\title{
Salivary proteome of a Neotropical primate: potential roles in host defense and oral food perception
}

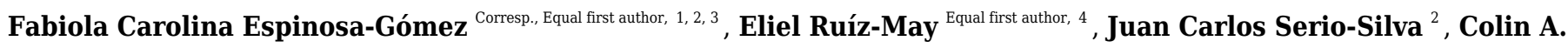
Chapman ${ }^{1,5,6,7}$

1 Dept. of Anthropology and McGill School of Environment, McGill University, Montreal, Quebec, Canada

2 Red de Biología y Conservación de Vertebrados, Instituto de Ecología AC, Xalapa, Veracruz, Mexico

3 Facultad de Medicina Veterinaria y Zootecnia, Universidad Popular Autonóma del Estado de Puebla, Puebla, Puebla, Mexico

4 Red de Estudios Moleculares Avanzados, Instituto de Ecología AC, Xalapa, Veracruz, Mexico

5 Department of Anthropology, Center for the Advanced Study of Human Paleobiology, George Washington University, Washington DC, Washington DC, United States

6 School of Life Sciences, University of KwaZulu-Natal, Scottsville, Pietermaritzburg, South Africa

7 Shaanxi Key Laboratory for Animal Conservation, Northwest University, Xi'an, Xi'an, China

Corresponding Author: Fabiola Carolina Espinosa-Gómez

Email address: fabiolacarolina.espinosa@upaep.mx

Background. Saliva contains a very complex mixture of proteins for defense against microbiological pathogens and for oral food perception. Howler monkeys are Neotropical primates that can consume a mostly leaf diet, they are well known to thrive in highly disturbed habitats where may cope with a diversity of dietary challenges and infection risks. We aimed to describe the salivary proteome of howlers to contribute to better understanding of their physiology. Methods. We analyzed the salivary proteins of wild black howler monkeys (Alouatta pigra), by SDS-PAGE-1-D and Nano LC-MS/MS and categorized them by their function involved in host defense and oral food perception. Results. Our proteomic analysis identified 156 proteins in howler saliva including a number of host defense peptides that are the first line of defense in mammals, such as defensin, cathelicidin, dermcidin, and lactotransferrin, and proteins with anti-bacterial, anti-fungal, and anti-viral capacity, such as $\lg \mathrm{A}, \lg \mathrm{G}, \lg \mathrm{M}, \mathrm{BPI}$, salivary heat shock $70 \mathrm{kDa}$ protein, beta-2-microbulin, and protein S-100. We also identified key proteins necessary for taste perception, including salivary carbonic anhydrase VI, cystatin D, IgA, and fatty acid-binding protein. Proteins to detect astringent foods were identifying, including four members of cystatins ( $A, B, C$ and $D$ ), lactoperoxidase, and histidine-rich proteins. No chitinase and amylase were identified as would be expected because howlers do not eat insects and little starch. These findings provide basic information to future studies in oral biology, ingestive physiology, and physiological ecology of mammals and non-human primates. 


\section{Salivary proteome of a Neotropical primate: potential roles 2 in host defense and oral food perception}

3 Fabiola Carolina Espinosa-Gómez ${ }^{1,2,3^{*}}$, Eliel Ruíz-May ${ }^{4 *}$, Juan Carlos Serio-Silva ${ }^{2}$, and Colin A.

4 Chapman 1,5

5

$6{ }^{1}$ Dept. of Anthropology and McGill School of Environment, McGill University, Montreal, 7 Quebec, Canada

$8 \quad{ }^{2}$ Red de Biología y Conservación de Vertebrados, Instituto de Ecología AC, Xalapa, México

$9{ }^{3}$ Facultad de Medicina Veterinaria y Zootecnia. Universidad Popular Autónoma del Estado de

10 Puebla, Puebla, México

$11{ }^{4}$ Red de Estudios Moleculares Avanzados, Instituto de Ecología AC, Xalapa, México

$12{ }^{5}$ Department of Anthropology, Center for the Advanced Study of Human Paleobiology, George

13 Washington University, Washington DC, United States.

$14{ }^{6}$ School of Life Sciences, University of KwaZulu-Natal, Scottsville, Pietermaritzburg, South

15 Africa

$16{ }^{7}$ Shaanxi Key Laboratory for Animal Conservation, Northwest University, Xi'an, China

$17 *$ These authors contributed equally to this work.

18

Corresponding Author: Fabiola Carolina Espinosa-Gómez, 21 sur \#1103, Barrio de Santiago, 20 21 
37 Abstract

38 Background. Saliva contains a very complex mixture of proteins for defense against

39 microbiological pathogens and for oral food perception. Howler monkeys are Neotropical

40 primates that can consume a mostly leaf diet, they are well known to thrive in highly disturbed

41 habitats where may cope with a diversity of dietary challenges and infection risks. We aimed to

42 describe the salivary proteome of howlers to contribute to better understanding of their

43 physiology.

44 Methods. We analyzed the salivary proteins of wild black howler monkeys (Alouatta pigra), by

45 SDS-PAGE-1-D and Nano LC-MS/MS and categorized them by their function involved in host

46 defense and oral food perception.

47 Results. Our proteomic analysis identified 156 proteins in howler saliva including a number of

48 host defense peptides that are the first line of defense in mammals, such as defensin, cathelicidin,

49 dermcidin, and lactotransferrin, and proteins with anti-bacterial, anti-fungal, and anti-viral

50 capacity, such as IgA, IgG, IgM, BPI, salivary heat shock $70 \mathrm{kDa}$ protein, beta-2-microbulin, and

51 protein S-100. We also identified key proteins necessary for taste perception, including salivary

52 carbonic anhydrase VI, cystatin D, IgA, and fatty acid-binding protein. Proteins to detect

53 astringent foods were identifying, including four members of cystatins (A, B, C and D),

54 lactoperoxidase, and histidine-rich proteins. No chitinase and amylase were identified as would

55 be expected because howlers do not eat insects and little starch. These findings provide basic

56 information to future studies in oral biology, ingestive physiology, and physiological ecology of

57 mammals and non-human primates.

58

59

60

61

62

63

64

65

66

67

68

69

70

71

72

\section{Introduction}

Saliva plays a crucial role handling both nutritious and toxic foods. Saliva maintains oral health by protecting the digestive tract, maintaining tooth strength, and providing antimicrobial activity against bacteria, viruses, and fungus (Fábián et al., 2012). Oral food perception is facilitated by salivary proteins (Canon \& Neyraud 2016; Rodrigues et al., 2017; Fábián et al., 2015), so that individuals may choose a nutritious diet and avoid harmful secondary metabolites or toxins found in some foods (Lamy et al., 2017). The function of saliva can vary with diet and its proteome may be influenced by pathogens (Thamadilok et al., 2019; Karasov \& Douglas, 2013; Lamy, et al., 2010; Da Costa, et al., 2008). Thus, physical and chemical properties of saliva, specially its proteome, relates to the animal's health and their ability to feed safely in particular kinds of environment (Lamy \& Mau, 2012).

Saliva plays an important role in defense against pathogens. Research on oral biology in humans and other mammal species has identified that salivary proteins and peptides displayed additive and synergistic anti-bacterial, antiviral, and anti-fungal functions (Fábián et al., 2012;

73 Wang, Peterson \& Loring, 2014). Salivary components allowing this include: immunoglobulins, 74 chaperone $70 \mathrm{kDa}$ heat shock proteins, lysozyme, amylase, histatins, proline-rich proteins 75 (PRPs), peroxidases, mucins, bactericidal/permeability-increasing protein (BPI), BPI-like 76 proteins, palate lung and nasal epithelial clone proteins (PLUNC), proteins S100, clusterin, defensin, and statherin (Amerongen \& Veerman, 2002; Amerongen, Bolscher \& Veerman, 2004;

78 Carneiro et al., 2012; Fábián et al., 2012). 
80

81

82

83

84

85

86

87

88

89

90

91

92

93

94

95

96

97

98

99

100

101

102

103

104

105

106

107

108

109

110

111

112

113

114

115

116

117

Food preferences also may correspond to the expression of some peptides and proteins in saliva, and the taste sensitivity for specific tastants (Salles et al., 2010; Canon \& Neyaroud, 2016). The gustatory sensation is the result of the interaction of water-soluble chemicals in the mouth with the taste buds, this interaction is mediated by ions, hormones and salivary proteins that function as tastant-binding proteins (Scott, 2005; Fábián et al., 2015; Canon \& Neyaroud, 2016). For instance, sweet-taste sensitivity in humans is related with higher levels of cystatins and lower levels of amylase in saliva (Rodrigues et al., 2017). Other salivary proteins allow fatty acid taste perception (Mounayar et al., 2014), such as carbonic anhydrase VI (CA-VI), cystatin $\mathrm{SN}$, cystatin $\mathrm{D}$, zinc-alpha-2-glycoprotein, fatty-acid binding protein, and proline-rich proteins (PRPs).

Other salivary proteins participate in the detection of astringency when they interact with plant secondary metabolites, such as polyphenols (Horne, Hayes \& Lawless, 2002). This tactile sensation represents a warning cue discouraging the ingestion of foods with high concentrations of polyphenols (e.g. tannins), which are a plant defense against herbivory (Freeland, 1991). Salivary proteins precipitate polyphenols preventing its negative physiological effects (Bennick, 2002). It has been found in humans and some mammals, increased levels of some salivary proteins (e.g., basic PRPs, cystatin, statherin, histatins (histidine-rich proteins), mucins, amylase, $\operatorname{IgA}$, glycoprotein 1 and 2) in response to astringent compounds that collaborate with the acceptance of food to make it less aversive and more palatable (Canon \& Neyaroud, 2016; Martin, Kay \& Torregrosa, 2018; Nayak \& Carpenter, 2008; Ployon et al., 2018; Torregrosa et al., 2014).

The diet of herbivorous represents a significant challenge because their foods contain different types and concentrations of plant secondary metabolites (Foley, Iason \& McArthur, 1999). Among them, tannins are one of the most studied and they deter herbivore feeding through two principal effects. The first involves making foods unpalatable as they have an astringent and bitter taste (Horne, Hayes \& Lawless, 2002). The second involves binding dietary proteins and digestive enzymes reducing protein and food digestibility (Austin, et al., 1989; Martinez-Gonzalez et al., 2017; Moore et al., 2014; Robbins et al., 1987). Therefore, salivary proteins are the first line of defense against dietary tannins (Shimada, 2006).

Howler monkeys (genus Alouatta) are the most folivorous New World primate and have the widest geographical distribution of any primate in the Americas. These monkeys do well in highly fragmented and perturbed landscapes (Kowalewski et al., 2015; Chaves \& BiccaMarques, 2016), which may mean that they select the right foods and have an effective hostdefense system. Their diet is leaf-based or fruit-based according food availability (Dias \& Rangel-Negrín, 2015). Their ability to eat fibrous (Espinosa-Gómez et al., 2013) tannin-rich leaves and toxic unripe fruits contribute to their adaptability (Garber, Righini \& Kowalewski 2015; Milton 1979). Black howler monkeys (Alouatta pigra) can consume plants with high concentration of tannins (Espinosa-Gómez et al., 2018; Righini, Garber \& Rothman, 2017) and these monkeys continuously secrete salivary proteins with tannin-binding affinity (Espinosa- 
118 Gómez et al., 2018). Their tannin-binding salivary proteins (TBSPs) might be PRPs, but this

119

120

121

122

123

124

125

126

127

128

129

130

131

132

133

134

135

136

137

138

139

140

141

142

143

144

145

146

147

148

149

150

151

152

153

154

155

156

157

remains to be confirmed (Espinosa-Gómez et al., 2018).

Black howler monkeys face habitat loss and fragmentation, and thus deal with nutritional stress and a high risk of disease transmission (Kowalewski et al., 2011; Chapman, Gillespie \& Goldberg, 2005; Chapman et al., 2013). The objectives of our study are to (i) identify the proteins of whole saliva of black howler monkeys (Alouatta pigra) by proteomic analysis, (ii) distinguish proteins/peptides related to oral food perception, and (iii) characterize proteins related with host-defense and antimicrobial properties:

\section{Materials \& Methods}

Saliva samples

All research protocols reported here were reviewed and approved by the government of Mexico (SEMARNAT SGPA/DGVS/10426/14) and complied with the legal and ethical guidelines of the IUCN (1998), and of the Mexican authorities (Diario Oficial de la Federación, 1999). We used the saliva samples obtained by FCEG as part of a complementary research project to evaluate the relationship of dietary tannins and tannin-binding salivary proteins (Espinosa-Gómez, 2017, unpublished data).

Samples were obtained from 14 free-ranging black howler monkeys occupying four

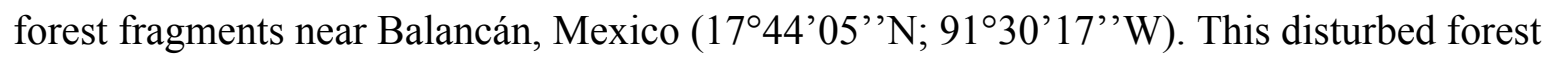
landscape lies within cattle pastures (Pozo-Montuy et al., 2013). Monkeys were darted and anaesthetized by a veterinarian with ketamine hydrochloride $(8 \mathrm{mg} / \mathrm{kg}$ estimated body mass, Ketaset, Fort Dodge Animal Health, Iowa USA). Once monkeys were stabilized following sedation, the body weight was determined and the saliva flow was stimulated by an intramuscular administration of the parasympathomimetic compound pilocarpine-hydrochloride $(0.5$ mg/ body mass) (Espinosa-Gómez et al., 2018; Da Costa et al., 2008). The whole saliva was collected from the mouth of each monkey using a micropipette, placed in a tube, and immediately frozen in liquid nitrogen. All saliva samples were transported from the field to the Proteomic Lab at INECOL, AC in Xalapa, Veracruz, México in a cryogenic container and then stored in an ultra freezer at $-80^{\circ} \mathrm{C}$ until analysis.

\section{Saliva preparation and SDS-PAGE}

At the lab, saliva aliquots were thawed, cells and debris were removed by centrifugation at $16,000 \mathrm{~g}$ for $10 \mathrm{~min}$ at $4^{\circ} \mathrm{C}$, and the supernatant was captured. We determined the salivary total protein concentration by the Bradford method (Bradford, 1976) using bovine serum albumin (BSA) as a standard. Absorbance was measured at $595 \mathrm{~nm}$ with a microtiter plate reader (SpectroMAX 340, Molecular Devices, Union City, CA, USA). We fractionated salivary proteins using $12 \%$ one-dimensional sodium dodecyl sulfate-polyacrylamide gel electrophoresis (SDS-PAGE) following Laemmli (Laemmli, 1970). The 1D-SDS PAGE $(8 \times 7.3 \mathrm{~cm} \times 1.5 \mathrm{~mm})$ was run with $30 \mu \mathrm{g}$ of salivary total protein with SDS loading buffer 4:1 (Biorad, CA, USA). Molecular mass markers (Precision Plus Protein Dual Color Standards, BioRad 1610374, CA, 
158

159

160

161

162

163

164

165

166

167

168

169

170

171

172

173

174

175

176

177

178

179

180

181

182

183

184

185

186

187

188

189

190

191

192

193

194

195

196

197

198

USA) were run in each gel to calibrate the molecular masses of the salivary proteins. Protein bands were fixed with a mixture of $26 \%$ ethanol, $14 \%$ formaldehyde, and $60 \%$ water for $3 \mathrm{hr}$, followed by $3 \mathrm{hr}$ in a mixture of 50\% methanol and $12 \%$ acetic acid (Steck, Leuthard, \& Bürk, 1980). We followed the procedures suggested by Beeley et al., (1991) to detect PRPs, which allows PRPs stain pink or pinkviolet. Briefly, gels were stained overnight with a $0.25 \%$ Coomassie brilliant blue R-250 solution (Biorad 1610400) in 40\% (v/v) methanol and 10\% (v/v) acetic acid. We de-stained the protein bands with several changes of $10 \%$ acetic acid.

\section{In-gel digestion proteins}

The clear proteins bands observed in our protein gels provided sufficient clean samples for proteomic analysis using the Nano LC-MS/MS approach. Protein bands were manually removed from gels and cut into 13 different molecular weight ranges (bands a - $\mathrm{m}$ ) by excising these regions with a sharp straight edge and then destained with $2.5 \mathrm{mM}$ ammonium bicarbonate (NH4HCO3) in $50 \%$ acetonitrile (ACN), and then dehydrated with $100 \mu \mathrm{L}$ of $100 \% \mathrm{ACN}$. Samples were then reduced with $20 \mu \mathrm{l}$ of $10 \mathrm{mM}$ DTT in $50 \mathrm{mM} \mathrm{NH4HCO3}$ and incubated for $45 \mathrm{~min}$ at $56^{\circ} \mathrm{C}$. Subsequently, the samples were cooled to room temperature and proceeded with the alkylation by adding $20 \mu \mathrm{L}$ of $100 \mathrm{mM}$ iodoacetamide in $50 \mathrm{mM} \mathrm{NH} 4 \mathrm{HCO}$, and incubating in the dark for $30 \mathrm{~min}$. Then, the samples were washed with $100 \mu \mathrm{L}$ of $100 \% \mathrm{ACN}$ for $5 \mathrm{~min}$, then with $\neg 100 \mu \mathrm{L}$ of $5 \mathrm{mM}$ NH4HCO3 for $5 \mathrm{~min}$ and then with $100 \mu \mathrm{L}$ of $100 \%$ ACN for 5 min. Finally, samples were dried with CentriVap (Labconco Kansas, Missouri) for 5 min and rehydrated with $10 \mu \mathrm{L}$ of digestion solution containing $12.5 \mathrm{ng} / \mu \mathrm{L}$ mass spectrometry grade Trypsin Gold (Promega, Madison, WI, USA) in $5 \mathrm{mM} \mathrm{NH4HCO} 3$ and incubated in a water bath at $37^{\circ} \mathrm{C}$ overnight. The reaction was stopped at $-80{ }^{\circ} \mathrm{C}$. The peptides were extracted with $30 \mu \mathrm{L}$ of $50 \%$ acetonitrile with $5 \%$ formic acid by centrifugation at $1000 \mathrm{x}$ for $30 \mathrm{~s}$ and desalted with ZipTip- $\mu \mathrm{C} 18$ tips (Merck Millipore, Darmstadt, Germany) and dried using a CentriVap (Labconco Kansas, Missouri, USA).

\section{Mass spectrometry (Nano LC-MS/MS analysis)}

Suspended samples ( $5 \mu \mathrm{l}$ of $0.1 \%$ formin acid) were injected into a nanoviper C18 trap column $(3 \mu \mathrm{m}, 75 \mu \mathrm{m}$ X $2 \mathrm{~cm}$, Dionex) at $3 \mu \mathrm{min}-1$ flow rate and separated on an EASY spray C18 RSLC column $(2 \mu \mathrm{m}, 75 \mu \mathrm{m} \times 25 \mathrm{~cm})$ with a flow rate of $300 \mathrm{nl}$ min-1 connect to an UltiMate 3000 RSLC system (Dionex, Sunnyvale, CA) and interfaced with an Orbitrap FusoinTM TribidTM (Thermo-Fisher Scientific, San Jose, CA) mass spectrometer equipped with an "EASY Spray" nano ion source (Thermo-Fisher Scientific, San Jose, CA). For peptide separation, a chromatographic gradient using MS grade water (solvent A) and $0.1 \%$ formic acid in $90 \%$ acetonitrile (solvent B) for 30 min was set as followed: 10 min solvent A, 7-20\% solvent B within $25 \mathrm{~min}, 20 \%$ solvent B for $15 \mathrm{~min}, 20-25 \%$ solvent B for $15 \mathrm{~min}, 25-95 \%$ solvent B for $20 \mathrm{~min}$, and $8 \mathrm{~min}$ solvent $\mathrm{A}$. The mass spectrometer was operated in positive ion mode with nanospray voltage set at $3.5 \mathrm{kV}$ and source temperature at $280^{\circ} \mathrm{C}$. External calibrant included caffeine, Met-Arg-Phe-Ala (MRFA), and Ultramark 1621. The mass spectrometer was operated in a data-dependent mode to automatically switch between MS and MS/MS. The survey full-scan 
199 MS spectra were acquired in the Orbitrap analyzer, scanning of mass range was set to 350-1500

200

201

202

203

204

205

206

207

208

209

210

211

212

213

214

215

216

217

218

219

220

221

222

223

224

225

226

227

228

229

230

231

232

233

234

235

236

237

238

$\mathrm{m} / \mathrm{z}$ at resolution of 120,000 (FWHM) using an automatic gain control (AGC) setting to 4.0e5 ions, maximum injection time to $50 \mathrm{~ms}$, dynamic exclusion 1 at $90 \mathrm{~S}$ and $10 \mathrm{ppm}$ mass tolerance. A top speed survey scan for $3 \mathrm{~s}$ were selected for subsequent decision tree-based Orbitrap collision-induced dissociation (CID) or higher-energy collisional dissociation (HCD) fragmentation (Swaney, McAlister \& Coon, 2008; Frese et al., 2011). The signal threshold for triggering an MS/MS event was set to $1.0 \mathrm{e} 4$ and the normalized collision energy was set to 35 and $30 \%$ for CID and HCD, respectively. The AGC of 3.0e4 and isolation window of $1.6 \mathrm{~m} / \mathrm{z}$ was set for both fragmentations. Additional parameter for CID included activation Q was set to $0.25 \mathrm{~ms}$ and injection time to $50 \mathrm{~ms}$. For HCD, first mass was set to $120 \mathrm{~m} / \mathrm{z}$ and injection time to $100 \mathrm{~ms}$. The settings for decision tree were as follows: for HCD fragmentation charge states 2 or 3 were scan in a range of $650-1200 \mathrm{~m} / \mathrm{z}$, charge states 4 were scan in a range of $900-1200 \mathrm{~m} / \mathrm{z}$, and charge states 5 were scan in a range of $950-1200 \mathrm{~m} / \mathrm{z}$; for CID fragmentation charge states 3 were scan in a range of $650-1200 \mathrm{~m} / \mathrm{z}$, charge state 4 were scan in a range of $300-900 \mathrm{~m} / \mathrm{z}$, and charge state 5 in scan range of 300-950 m/z. All data were acquired with Xcalibur 4.0.27.10 software (Thermo-Fisher Scientific).

\section{Database search and protein/peptide identification}

Raw data were analyzed with Proteome Discoverer 2.1 (PD, Thermo Fisher Scientific Inc.) and subsequent searches were carried out using Mascot server (version 2.4.1, Matrix Science, Boston, MA) and SQUEST HT (Eng et al., 1994). The search with both engines was conducted against Homo sapiens, Macaca fascicularis, Macaca mulatta, and the complete UniProt reference proteome (http://www.uniprot.org/). We included as parameters in the search: fulltryptic protease specificity, two missed cleavage allowed, static modifications covered carbamidomethylation of cysteine $(+57.021 \mathrm{Da})$. Furthermore, dynamic modifications included methionine oxidation $(+15.995 \mathrm{Da})$ and deamidation in asparagine/glutamine $(+0.984 \mathrm{Da})$. For the MS2 method, in which identification was performed at high resolution in the Orbitrap, precursor and fragment ion tolerances of $\pm 10 \mathrm{ppm}$ and $\pm 0.2 \mathrm{Da}$ were applied. Resulting peptide hits were filtered for maximum 1\% FDR using the Target Decoy PSM validator. We considered a MASCOT score $>20$ for proteins identified with two or more peptides and MASCOT score $>34$ for proteins identified with one single peptide.

\section{Bioinformatic Analysis}

Proteins were screened for the predicted presence of N-terminal endoplasmic reticulum (ER) targeting signal peptide (SP) using the Signal P 4.1 program

(http://www.cbs.dtu.dk/services/SignalP/, Petersen, et al., 2011). In addition, we used the server Secretome P 2.0 to determine non-classical and leaderless protein secretion in proteins identified in the saliva of monkeys (http://www.cbs.dtu.dk/services/SecretomeP/, Bendtsen et al., 2014). The program MHMM server v. 2.0 were used for the prediction of transmembrane helices in salivary proteins (http://www.cbs.dtu.dk/services/TMHMM/). Proteins were classified base on

Peer] reviewing PDF | (2020:01:44768:1:1:NEW 23 May 2020) 
239 GO ontology enrichment of biological processes using David ontology tool (Sherman, \& 240 Lempicki, 2009) (https://david.ncifcrf.gov/). We used REVIGO web server (http://revigo. irb.hr/)

241

242

243

244

245

246

247

248

249

250

251

252

253

254

255

256

257

258

259

260

261

262

263

264

265

266

267

268

269

270

271

272

273

274

275

276

277

278 with a median similarity for the visual representation of the clustering of biological processes.

\section{Search for proteins/peptides related with host-defense and taste sensitivity}

To distinguish the salivary proteins related with taste sensitivity (beside with astringent detection in mouth), host defense, and antimicrobial properties (anti-bacterial, antiviral and anti-fungal), we carried out detailed scrutiny of the UniProt functional annotation (http://www.uniprot.org/) and also reviewed papers on salivary proteomics/peptidomics from humans and other animals that have identified proteins with specific functions on immunity and taste sensitivity of food. Most of the salivary proteins related with a specific function in an animal specie, has been identified in several others, which suggest that their function is conserved across species.

\section{Results}

Salivary protein separation by SDS-PAGE

We observed similar salivary protein patterns on 1-D electrophoresis gels in all individuals. There were multiple bands $(\mathrm{a}-\mathrm{m}$ ) ranging from 10 to $250 \mathrm{kDa}$ (Figure 1), with the most intense protein bands being located at low molecular weight from 10-15 kDa $(\mathrm{k}, 1, \mathrm{~m})$. However, the intensity of the bands did vary, with the $\mathrm{j}$ band being more apparent in individuals P-M1 and P$\mathrm{F} 1$, the band $\mathrm{k}$ was more intense in $\mathrm{B}-\mathrm{F} 2$, and bands 1 and $\mathrm{m}$ displayed a darker and more significant area of staining in B-F2 and P-M1. We visualized a main protein band (j) with an apparent molecular mass between 22-30 kDa that displayed a pink staining, which might be PRP according to Beeley et al., (1991) and described in Espinosa-Gómez et al., (2018).

\section{Identification of salivary proteins by Nano LC-MS/MS}

We use proteomics to evaluate all 13-protein bands fractionated on SDS-PAGE-1D; we digested and subjected to LC MS-MS pools of the same protein band from all individuals, and 156 proteins were identified (Table S1). Among these, 55 were predicted with both signal peptide (SP) and transmembrane helices domains (TMHMM), including well-known secreted proteins, such as the Lactoperoxidase (P22079), Lactotransferrin (P02788), Serotransferrin (A5A6I6), the glycosylated Prosaposin (P07602), and the Histidine-rich glycoprotein (P04196). Besides, we were able to predict five non-secreted proteins with TMHMM (Fig. 2A). Using Secretome P 2.0 (http://www.cbs.dtu.dk/services/SecretomeP/, (Bendtsen et al., 2004) we predicted ten proteins with a non-classical and leaderless secretion that include for example, Galectin-7 (P47929), Putative ubiquitin-conjugating enzyme E2 N-like (Q5JXB2), Putative ubiquitin-conjugating enzyme E2 N-like (Q5JXB2).

After gene ontology enrichment by David Bioinformatics Resources 6.8 (https://david.ncifcrf.gov/, Huang et al., 2009) and clustering by REVIGO web server (http://revigo. irb.hr/, Supek et al., 2011), we obtained a tree map displaying key biological processes associated with howler monkey saliva, including negative regulation of endopeptidase 
279

280

281

282

283

284

285

286

287

288

289

290

291

292

293

294

295

296

297

298

299

300

301

302

303

304

305

306

307

308

309

310

311

312

313

314

315

316

317

activity, defense response to fungus, gluconeogenesis, protein folding, cytoskeleton organization, platelet degranulation, and epidermis development. Each of these major groups included several gene ontology (GO) groups (Fig. 2B). The most representative group corresponded to negative regulation of endopeptidase activity that clustered gene ontology, such as proteolysis (GO:0006508), protein stabilization (GO:0050821), retina homeostasis (GO:0001895), retinoic acid metabolism (GO:0042573), negative regulation of endopeptidase activity (GO:0010951), and negative regulation of endothelial cell chemotaxis (GO:2001027).

The second most prominent cluster was the defense response to fungus conglomerating GO like protein kinase A signaling (GO:0010737), complement activation classical pathway GO:0006958 (GO:0006958), defense response to fungus (GO:0050832), response to ethanol (GO:0045471), and zinc ion (GO:0010043). The third most representative cluster named gluconeogenesis gathered the GO oxidation-reduction process (GO:0055114), cellular aldehyde metabolism (GO:0006081), and gluconeogenesis (GO:0006094).

Howler monkey salivary proteins associated with host-defense in mammals

It is widely recognized that salivary proteins have many functional properties, and some have more than one function. According to data available on UniProt functional annotation (http://www.uniprot.org/) and review papers on salivary proteomics/peptidomics from humans and other mammals, we identified 10 proteins with dual function, including oral food perception and host-defense $(6.4 \%$ of total identified proteins). We also identified proteins related with taste sensitivity or innate/acquired immunity (Fig. 3). We identified 28 salivary proteins/peptides (17.9\% of total identified proteins) associated with functions, such as host defense, innate immunity, and antimicrobial properties (anti-bacterial, antiviral and anti-fungal). There were identified cationic peptides, and defense proteins (such as immunoglobulins) that have been reported as effective against parasites, fungi and cancer cells. Table 1 presents the complete list of proteins/peptides identified in saliva of howler monkeys related with host-defense and antimicrobial properties, and the references where the link between these proteins and that immune function has been reported.

\section{Howler monkey salivary proteins associated with oral food perception}

We detected 16 proteins in saliva of howler monkeys (10.25\% of total identified proteins) related with oral food perception; the complete list is shown in Table 2. There were identified six proteins associated with gustatory sensitivity of sweet, salty, umami, fatty-acids, and pungent flavors. For instance, carbonic anhydrase VI or "gustin" was identified and plays an important role in human taste perception of fatty acids (Morzel et al., 2014). Likewise we identified four types of cystatins, histidine-rich glycoprotein, and $\operatorname{IgA}$, which are associated with a major inhibition of the feeling of astringency and bitter taste (Nayak \& Carpenter, 2008; Canon \& Neyaroud, 2016; Shimada, 2006). 


\section{Discussion}

319 We identified 156 salivary proteins from black howler monkey (Alouatta pigra); a leaf and fruit 320 eating primate that belongs to the most folivorous New World primate genus. The distinct

321

322

323

324

325

326

327

328

329

330

331

332

333

334

335

336

337

338

339

340

341

342

343

344

345

346

347

348

349

350

351

352

353

354

355

356

357 proteins identified belong to most protein families described in mammals (de Sousa-Pereira et al., 2015); we categorized them according their likely function based on previous literature, nevertheless, we only can speculate about the function of these salivary proteins related to host defense and oral food perception in howler monkeys. Some proteins we identified have dual functions in oral food perception and innate immunity, which molecular weights correspond to the protein bands with higher densities in 1D-SDS PAGE (10-17 kDa) as cystatins and histidinerich glycoprotein. This may indicate they are secreted in higher concentrations in saliva of howlers; however, their functional importance in howler monkey saliva remains to be investigated. We found by LC-MS/MS for the first time in saliva of primates, three types of salivary cystatins (A, B, and D); for instance, in humans have been described three S-type cystatins and C-cystatin (de Sousa-Pereira et al., 2014; Vitorino et al., 2004), also only S-type cystatins have been found in apes as western lowland gorillas (Gorilla gorilla) and chimpanzees (Pan troglodytes) (Thamadilok et al., 2019). Our results emphasize the essential physiological role that salivary proteins may have in maintaining the host-defense capacity and evaluating food properties, including taste and astringency. To the best of our knowledge, our study provides the first evaluation of the salivary proteome of a wild Neotropical primate. We provide a high number of predicted intracellular proteins - up to $57.05 \%$ of total identified proteins. Some proteins were predicted to have non-classical secretion (Fig. 2A, Table S1), thus, further experimental validation of their subcellular location is needed.

\section{Salivary proteins linked with host-defense in mammals}

A major finding of our research with howler monkeys is the identification salivary proteins and cationic molecules belonging to the two major antimicrobial peptides families: cathelicidins and defensins that rapidly inactivate infectious agents (Wiesner \& Vilcinskas, 2010; Zanetti, 2005). Cathelicidins have been identified in cattle, sheep, rat, and dogs, but not in humans (de SousaPereira et al., 2015). We also identified the antimicrobial peptide dermcidin that is recognized as a first line of skin defense in primates and has been identified in eccrine sweat glands of humans. Some argue that dermcidin is not found in other body fluids, such as nasal secretions, tears, saliva, semen, milk, and urine (Schittek, 2012); however, we identified this peptide in saliva of howler monkeys and it has been found in tears and cervicovaginal fluid in humans (Shaw, Smith \& Diamandis, 2007). Dermcidin-homologous genes exist only in apes (Pan troglodytes, Gorilla gorilla, Pongo abelii) and Old and New World monkeys (Schittek, 2012).

Our proteomic analysis identified four members of the cystatin family (A, B, C, and D) in saliva of howlers that may inhibit the action of endogenous, bacterial, and parasitic protozoan proteases (Fábián et al., 2012). Similarly, the GO analysis of the salivary proteins indicates the most representative group corresponded to negative regulation of endopeptidase activity (Fig. 2B). Cystatins comprise a large superfamily of related proteins with diverse biological activities 
358

359

360

361

362

363

364

365

366

367

368

369

370

371

372

373

374

375

376

377

378

379

380

381

382

383

384

385

386

387

388

389

390

391

392

393

394

395

396

found in variable tissues, but salivary cystatins are important due their functions in immunimodulation, antimicrobial, and antiviral (Dickinson, 2002). A number of members of this protein family have been identified in saliva of humans (Carneiro et al., 2012) and in different mammals (e.g., cystatin $\mathrm{D}$ has been found in rat, cystatin $\mathrm{S}$ in dogs, cystatin $\mathrm{C}$ is present in Artiodactyla, Rodentia, Lagomorpha, Carnivora, and Primates (de Sousa-Pereira et al., 2015).

As one would expect, we identified carbonic anhydrase VI (CA-VI), which is an active mammalian isozyme specifically secreted by salivary glands that have multiple functions (Kivelä et al., 1999). The CA-family are zinc metalloenzymes responsible for the conversion of carbon dioxide to bicarbonate $(\mathrm{CO} 2+\mathrm{H} 2 \mathrm{O} \leftrightarrow \mathrm{HCO} 3)$, which buffers saliva. CA-VI also has the ability to bind enamel and act in $\mathrm{pH}$ homeostasis of oral cavity and prevention of dental caries (Kimoto et al., 2006). Adding strength to the host-defense capacity of Alouatta pigra, we identified lactoperoxidase LPO, bactericidal permeability-increasing protein BPI, and histidine-rich glycoprotein, that are primarily responsible for innate immunity (Bingle \& Craven, 2004; Marra et al., 1990; Shin et al., 2011; Wiesner et al., 2010; Wijkstrom-Frei, et al., 2003). The microglobulin we identified is critical for immune modulation in vertebrate animals and has been identified as a biomarker for cancer cells malignancies (Li et al., 2016). Salivary heat shock 70 $\mathrm{kDa}$ protein may represent an important immune defense mechanism in saliva of howlers, as this protein has been identified in humans to bind bacteria and increases the release of proinflammatory cytokines from immune cells (Fábián, et al., 2012; 2009). It is important to emphasize the presence of three salivary secretory immunoglobulins in saliva of howlers as IgA, $\mathrm{IgG}, \operatorname{IgM}$ and other five isoforms (Table 1). IgA is known to induce an antigen-unspecific manner by commensal microbiota; therefore, these secretory antibodies may bind multiple antigens and are thought to eliminate commensal bacteria and self-antigens to avoid systemic recognition (Schroeder \& Cavacini, 2010; Teeuw et al., 2004).

Several salivary proteins related with innate immunity of mammals were not identified in black howler monkeys (e.g., mucins de Sousa-Pereira, et al., 2015). The failure to detect mucins may be due to the difficulty of assessing these proteins because of their large molecular mass, high viscosity, and poor solubility in aqueous solvents (Herzberg et al., 1979). However, we recognized that our preparation procedure of saliva samples, using $16000 \mathrm{~g} \mathrm{x} 10$ min to separate the supernatant could result in loss of mucins in the precipitate. Other important proteins highly related to oral homeostasis, such as sthaterins and PRPs were also not identified.

We actually observed pink-staining bands in our SDS-PAGE gels, following the procedures suggested by Beeley et al. (1991) to detect PRPs, suggesting the presence of these proteins; however, some factors in our method could have interfered to detect PRPs such as the centrifugation process, and the use of trypsin for the protein digestion. Moreover, it is known that the identification of PRPs by mass spectrometry is unusually difficult (Leymarie et al., 2002); it could be possible that multiple PTM generated specific mass spectrum of modified peptides, which mass $/$ charge $(\mathrm{m} / \mathrm{z})$ values could match with public databases (Kim, Zhong \& Pandey, 2016). It is also possible that the sequences of PRPs are highly specific in Alouatta pigra. 
397

398

399

400

401

402

403

404

405

406

407

408

409

410

411

412

413

414

415

416

417

418

419

420

421

422

423

424

425

426

427

428

429

430

431

432

433

434

435

436

Many of the proteins identified in howler monkey saliva are likely components of the early mammalian host defense against infection (de Sousa-Pereira, et al., 2015). However, howler monkey saliva may have evolved a specific set of protein families to help them cope with infection risk and permit them to deal with habitat loss, fragmentation, and nutritional stress. (Chapman et al., 2005; Chapman et al., 2013). Zoonotic protozoa infection is related to degree of human contact with wild howler monkeys (Kowalewski et al., 2011).

\section{Salivary proteins linked with taste perception and food preference}

We identified several important proteins in saliva of howler monkeys that might allow them to be selective and discerning while feeding, likely facilitate their feeding selectivity. Salivary proteins to perceive beneficial traits of food were found (e.g., CA-VI, lactotransferrin, ER-Golgi intermediate compartment $53 \mathrm{kDa}$ protein, microbulin, defensing, cystatin $\mathrm{D}$, fatty acid-binding protein, salivary heat shock $70 \mathrm{kDa}$ protein, and IgA). We also identified salivary proteins that have been related to acceptance/detection of bitter and astringent solutions in humans, which may help howler monkeys to perceive and cope with negative characteristics of food, such as bitterness and astringency (related to plant secondary metabolites and toxic compounds) including cystatins (Desamou et al., 2012; Morzel et al., 2014; Mounayar et al., 2014; Quintana et al., 2009), histidine-rich glycoprotein (Dinnella et al., 2010), albumin and IgA (Desamou et al., 2012). The feeding flexibility of howler monkeys enables them to thrive in small and disturbed habitat patches, where food scarcity is common (Chaves \& Bicca-Marques, 2016). To our knowledge, physiological studies on taste in howler monkeys have not been conducted and there are no data of taste detection thresholds or on the ability to discriminate between different qualities of tastants (Hernández-Salazar, Dominy \& Laska, 2015). Consequently, for now we can only assume that the salivary proteins that we identified help these primates to choose the right diet.

Humans can differentiate among five flavors: sweet, sour, salty, bitter and umami (Van Dongen et al., 2012); although recently it has been proposed that humans can taste fatty acids (Mattes, 2011). Generally, it is accepted that each taste quality in food is related to its nutritional content (e.g., sweetness is associated with sugar, mono, and disaccharides; saltiness with sodium and protein content (van Dongen et al., 2012); and umami with sodium and protein (van Langeveld et al., 2017). Also, gustatory stimuli categorized as bitter and sour are associated with compounds that are potentially harmful (e.g., free protons or organic acid; bitter taste is related some toxins, Lamy et al., 2016).

Howler monkeys are herbivorous energy-maximizers and their diet is mainly leaves and ripe/unripe fruits (Chapman, 1987; Chapman, 1988; Righini, Garber \& Rothman, 2017), but they can feed only on leaves for extended periods (Behie \& Pavelka, 2005). A fruit-based diet is linked with a low protein intake and a decrease in mineral concentration (Silver et al., 2000), which may require selecting protein-rich and mineral-rich food items. For this purpose, howlers may benefit by secreting salivary proteins associated with gustatory sensitivity of salty and umami flavors (e.g., beta-defensin, CA-VI; cystatin D, and fatty acid-binding protein, IgA, 
437 salivary heat shock $70 \mathrm{kDa}$ protein, Table 2). A leaf-diet is a diet poor in energy and fatty-acids, 438 but high in fiber and often tannins (Righini, Garber \& Rothman, 2017; Espinosa-Gómez et al., 439 2018), which makes selecting food difficult (Silver et al., 2000). Under these conditions, 440 monkeys should select food items high in energy (carbohydrates, fatty-acids), but low in PSMs 441 (tannins). Some studies in humans have found a relationship between sweet taste sensitivity and 442 salivary proteins as cystatins (Rodrigues et al., 2019) and CA-VI (Rodrigues et al., 2017). We

443

444

445

446

447

448

449

450

451

452

453

454

455

456

457

458

459

460

461

462

463

464

465

466

467

468

469

470

471

472

473

474

475

476 found in howler monkeys saliva four varieties of cystatins (Table 1 and 2), which may help them to increase their sensitivity for sweet foods, although it remains to be investigated. For fattyacids or lipids, it has been shown that these nutrients are important in the diet of howler monkeys (Righini, Garber \& Rothman, 2017) and free fatty acids are one of the most abundant classes of nutrient metabolites in black howler monkeys foods (Amato et al., 2017). CA-VI or "gustin" plays principal role in taste sensitivity of fatty acids and sweet, salty, and sour flavors (Feeney \& Hayes, 2014).

Corresponding to howler monkeys' ability to feed on tannin-rich diet (Espinosa-Gómez et al., 2015; Espinosa-Gómez et al. 2018), we identified several salivary proteins that have been related with the capacity to accept astringent and bitter foods e.g., cystatins (Dsamou et al., 2012; Dinella et al., 2010; Quintana et al., 2009), glyceraldehyde-3-phosphate (Quintana et al., 2009), lactoperoxidase (Morzel et al., 2014), histidine-rich glycoproteins (Dinella et al., 2010), and albumin (Dsamou et al., 2012) (Table 2). PRPs, histatins, statherins, cystatins, and amylase are salivary proteins with considerable affinity for tannins and are involved in astringency and bitter taste (Lamy et al., 2016; Torregrosa et al., 2014)). We did not identify the well-known salivary PRPs and statherins identified as first line of defense against tannins (Shimada, 2006). However, we observed in our electrophoresis gels strong bands with pink-staining that may indicate the presence of PRPs (Beeley et al., 1991). Similarly, mucins also seem to have a role in astringency, but we did not identify mucins. This may be linked to their high molecular mass, high viscosity, and poor solubility in aqueous solvents (Lamy et al., 2010).

This study supports the suggestion that $\alpha$-amylase is not a component of saliva of animals feeding only on plants due their low ingestion of starch (Boehlke, Zierau \& Hannig, 2015), as this enzyme was not identified in saliva of howlers. Also, chitinase was not found in our proteomic analysis, which is consistent with howlers' feeding behavior as this protein has been identified in insectivorous-omnivorous non-human primates (Tabata et al., 2019).

\section{Conclusions}

Our research characterized the salivary protein of wild black howler monkeys and for the first time used a proteomic approach. We identified salivary proteins involved in host defense and oral food perception that helps understand the ecological adaptability of this species. However, for now we can only speculate that their salivary protein array is an advantage to face infection risk and low quality diets present in disturbed habitats (Chapman et al., 2013; Chapman et al., 2005). Salivary protein composition correlates with the feeding behavior of herbivorous primary feeders with energy-maximizing strategy. We also identified several important proteins involved 
477 with detection of astringency and bitterness. Correspondingly to their low starch and

478 invertebrates-free diet, we did not identify salivary amylase or chitinase. The identification of 28

479 proteins in saliva of howlers that have been described with anti-bacterial, anti-fungal, and anti-

480 viral capacity, might be involved to facilitate this species' ecological adaptability.

481

482

483

484

485

486

487

488

489

490

491

492

493

494

495

496

497

498

499

500

501

502

503

504

505

506

507

508

509

510

511

512

513

514

515

516

\section{Acknowledgements}

We thank Javier Hermida (DVM) for his professional support during the capture of the monkeys. We especially appreciate the work and dedication of field assistants Dolores Tejero, Antonio Jauregui, Monserrat Ayala, Celina Oliva, and Tonatiuh Fernando. We are also very grateful to José Miguel Elizalde-Contreras for his invaluable advice and work at the proteomic lab. The authors thank to Marcus Clauss for helpful comments on this manuscript.

\section{References}

Amato, K. R., Ulanov, A., Ju, K. S., \& Garber, P. A. 2017. Metabolomic data suggest regulation of black howler monkey (Alouatta pigra) diet composition at the molecular level. American Journal of Primatology, 79(4), 1-10.

Amerongen, A. V. \& Veerman, E. C. 2002. Saliva-the defender of the oral cavity. Oral Diseases, $8(1), 12-22$.

Amerongen, A. V., Bolscher, J. G. M., \& Veerman, E. C. I. 2004. Salivary proteins: protective and diagnostic value in cariology? Caries Research, 38(3), 247-253.

Austin, P.J., Suchar, L. A., Robbins CT, Hagerman AE. 1989. Tannin-binding proteins in saliva of deer and their absence in saliva of sheep and cattle. Journal of Chemical Ecology, 15(4), 1335-1347.

Balbin, M., Hall, A., Grubb, A., Mason, R. W., Lopez-Otin, C., \& Abrahamson, M. 1994. Structural and functional characterization of two allelic variants of human cystatin D sharing a characteristic inhibition spectrum against mammalian cysteine proteinases. Journal of Biological Chemistry, 269(37), 23156-23162.

Becerra, L., Soares, R.V., Bruno, L.S., Siqueira, C.C., Oppenheim, F.G., Offner, G.D., \& Troxler, R.F. 2003. Patterns of secretion of mucins and non-mucins glycoproteins in human submandibular/sublingual secretion. Archives of Oral Biology, 48(2), 147-154.

Beeley JA, Sweeney D, Lindsay JC, Buchanan ML, Sarna L \& Khoo KS. 1991. Sodium dodecyl sulphate-polyacrylamide gel electrophoresis of human parotid salivary proteins. Electrophoresis, 12(12), 1032-1041.

Behie, A. M., \& Pavelka, M. S. 2005. The short-term effects of a hurricane on the diet and activity of black howlers (Alouatta pigra) in Monkey River, Belize. Folia Primatologica, 76(1), 1-9.

Bendtsen, J.D., Jensen, L.J., Blom, N., von Heijne, G. and Brunak, S., 2004. Feature-based prediction of non-classical and leaderless protein secretion. Engineering, Design and Selection, Volume 17, Issue 4, April 2004, Pages 349-356, https://doi.org/10.1093/protein/gzh037 
517 Bennick A. 2002. Interaction of plant polyphenols with salivary proteins. Critical Reviews in

518

519

520

521

522

523

524

525

526

527

528

529

530

531

532

533

534

535

536

537

538

539

540

541

542

543

544

545

546

547

548

549

550

551

552

553

554

555

Oral Biology \& Medicine 13(2), 184-196.

Biesbrock, A. R., Reddy, M. S., \& Levine, M. J. 1991. Interaction of a salivary mucin-secretory immunoglobulin A complex with mucosal pathogens. Infection and immunity, 59(10), 3492-3497.

Bingle, C. D., \& Craven, C. J. 2004. Meet the relatives: a family of BPI-and LBP-related proteins. Trends in Immunology, 25(2), 53-55.

Blaydon, D. C., Nitoiu, D., Eckl, K. M., Cabral, R. M., Bland, P., Hausser, I., and Zvulunov, A. 2011. Mutations in CSTA, encoding Cystatin A, underlie exfoliative ichthyosis and reveal a role for this protease inhibitor in cell-cell adhesion. The American Journal of Human Genetics, 89(4), 564-571.

Boehlke, C., Zierau, O., \& Hannig, C. 2015. Salivary amylase-The enzyme of unspecialized euryphagous animals. Archives of Oral Biology, 60(8), 1162-1176.

Bradford, M.M., 1976. A rapid and sensitive method for the quantitation of microgram quantities of protein utilizing the principle of protein-dye binding. Analytical biochemistry 72,248 254.

Canon F, Neyraud E. 2017. Interactions between saliva and flavour compounds. In: Guichard E, Salles C, Morzel M, Le Bon AM, ed. Flavour: From food to perception, John Wiley \& Sons. 284-309.

Carneiro, L. G., Venuleo, C., Oppenheim, F. G., \& Salih, E. 2012. Proteome data set of human gingival crevicular fluid from healthy periodontium sites by multidimensional protein separation and mass spectrometry. Journal of periodontal research, 47(2), 248-262.

Chapman, C. A., Ghai, R., Jacob, A., Koojo, S. M., Reyna-Hurtado, R., Rothman, J. M., \& Goldberg, T. L. 2013. Going, going, gone: a 15-year history of the decline of primates in forest fragments near Kibale National Park, Uganda. In: Marsh LK, Chapman CA (eds) Primates in fragments: complexity and resilience. Springer, New York, NY, p 89-100

Chapman, C. A., Gillespie, T. R., \& Goldberg, T. L. 2005. Primates and the ecology of their infectious diseases: How will anthropogenic change affect host-parasite interactions? Evolutionary Anthropology 14(4), 134-144.

Chapman, C.A. 1987. Flexibility in diets of three species of Costa Rican primates. Folia Primatologica 49:90-105.

Chapman, C.A. 1988. Patterns of foraging and range use by three species of neotropical primates. Primates 29:177-194.

Chaves, Ó. M., \& Bicca-Marques, J. C. 2016. Feeding strategies of brown howler monkeys in response to variations in food availability. PLoS One, 11(2), e0145819. doi:10.1371/journal.pone.0145819

Da Costa, G., Lamy, E., Capela e Silva, F., Andersen, J., Sales Baptista, E., Coelho, A. 2008. Salivary amylase induction by tannin-enriched diets as a possible countermeasure against tannins. Journal of Chemical Ecology 34(3), 376-387.

Peer) reviewing PDF | (2020:01:44768:1:1:NEW 23 May 2020) 
556 Dale, B. A., \& L. P. Fredericks. (2004). Antimicrobial peptides in the oral environment:

557

558

559

560

561

562

563

564

565

566

567

568

569

570

571

572

573

574

575

576

577

578

579

580

581

582

583

584

585

586

587

588

589

590

591

592

593

594

595 expression and function in health and disease, p. 223-251. In Gallo R. L. (ed.), Antimicrobial peptides in human health and disease. Horizon Bioscience, Wymondham, United Kingdom.

de Sousa-Pereira, P., Cova, M., Abrantes, J., Ferreira, R., Trindade, F., Barros, A., Gomes, P., Colac, B., Amado, F., Esteves, P.\& Vitorino, R. 2015. Cross-species comparison of mammalian saliva using an LC-MALDI based proteomic approach. Proteomics, 15(9), 1598-1607.

Dinnella, C., Recchia, A., Vincenzi, S., Tuorila, H. and Monteleone, E. (2010) Temporary modification of salivary protein profile and individual responses to repeated phenolic astringent stimuli. Chemical Senses, 35(1), pp. 75-85.

Dsamou, M., Palicki, O., Septier, C., Chabanet, C., Lucchi, G., Ducoroy, P., Chagnon, M. C. and Morzel, M. 2012. Salivary protein profiles and sensitivity to the bitter taste of caffeine. Chemical Senses, 37(1), pp. 87-95.

Diario Oficial de la Federación. 1999. Norma Oficial Mexicana NOM-062-ZOO-1999, 22 de Agosto de 2001.

Dias, P. A. D., \& Rangel-Negrín, A. 2015. Diets of howler monkeys. In Howler monkeys (pp. 21-56). Springer, New York, NY.

Dickinson, D. P. 2002. Salivary (SD-type) cystatins: over one billion years in the making-But to what purpose? Critical Reviews in Oral Biology \& Medicine, 13(6), 485-508.

Doumas, S., Kolokotronis, A., \& Stefanopoulos, P. (2005). Anti-inflammatory and antimicrobial roles of secretory leukocyte protease inhibitor. Infection and Immunity, 73(3), 12711274. e0208317. https://doi.org/10.1371/journal.pone.0208317

Eng, J. K., McCormack, A. L., \& Yates, J. R. 1994. An approach to correlate tandem mass spectral data of peptides with amino acid sequences in a protein database. Journal of the American Society for Mass Spectrometry, 5(11), 976-989.

Espinosa-Gómez, F. C., Serio-Silva, J. C., Santiago-García, J. D., Sandoval-Castro, C. A., Hernández-Salazar, L. T., Mejía-Varas, F., Ojeda-Chávez J. \& Chapman, C. A. (2018). Salivary tannin-binding proteins are a pervasive strategy used by the folivorous/frugivorous black howler monkey. American Journal of Primatology, 80(2), e22737.

Espinosa-Gómez, F., Gómez-Rosales, S., Wallis, I. R., Canales-Espinosa, D., \& HernándezSalazar, L. 2013. Digestive strategies and food choice in mantled howler monkeys Alouatta palliata mexicana: bases of their dietary flexibility. Journal of Comparative Physiology B, 183(8), 1089-1100.

Fábián, T. K., Beck, A., Fejérdy, P., Hermann, P., \& Fábián, G. 2015. Molecular mechanisms of taste recognition: considerations about the role of saliva. International Journal of Molecular Sciences, 16(3), 5945-5974.

Fábián, T. K., Gótai, L., Beck, A., Fábián, G., \& Fejérdy, P. 2009. The Role of Molecular Chaperones (HSPAs/HSP70s) in Oral Health and Oral Inflammatory Diseases: A 
596

597

598

599

600

601

602

603

604

605

606

607

608

609

610

611

612

613

614

615

616

617

618

619

620

621

622

623

624

625

626

627

628

629

630

631

632

633

634

Review. European Journal of Inflammation, 53-61.

https://doi.org/10.1177/1721727X0900700201

Fábián, T. K., Hermann, P., Beck, A., Fejérdy, P., \& Fábián, G. 2012. Salivary defense proteins: their network and role in innate and acquired oral immunity. International Journal of Molecular Sciences, 13(4), 4295-4320.

Feeney, E. L., \& Hayes, J. E. 2014. Exploring associations between taste perception, oral anatomy and polymorphisms in the carbonic anhydrase (gustin) gene CA6. Physiology \& Behavior, 128, 148-154.

Foley, W.J., Iason, G.R., \& McArthur, C., 1999. Role of plant secondary metabolites in the nutritional ecology of mammalian herbivores: How far have we come in 25 years? In: Jung HJ, Fahey GC., (ed). Nutritional ecology of herbivores: proceedings of the Vth International Symposium on the Nutrition of Herbivores. American Society of Animal Science, Savoy, Illinois, pp 130-209.

Freeland WJ. 1991. Plant secondary metabolites: biochemical coevolution with herbivores. In: Palo T, Robbins $C$, ed. Plant defenses against mammalian herbivory. Boca Raton, FL Florida: CRC Press, 61-81.

Frese, C. K, Altelaar, A. F. M., Hennrich, M. L., Nolting, D., Zeller, M., Griep-Raming, J., Heck, A. J. R., \& Mohammed, S. 2011. Improved peptide identification by targeted fragmentation using CID, HCD and ETD on an LTQ-Orbitrap Velos. Journal of proteome research, 10(5), 2377-2388.

Garber, P. A., Righini, N., \& Kowalewski, M. M. 2015. Evidence of alternative dietary syndromes and nutritional goals in the genus Alouatta. In Howler monkeys (pp. 85-109). Springer, New York, NY.

Geisberger, R., Lamers, M., \& Achatz, G. 2006. The riddle of the dual expression of IgM and IgD. Immunology, 118(4), 429-437.

Glander KE. 1982. The impact of plant secondary compounds on primate feeding behavior. American Journal of Physical Anthropology 25(S3), 1-18.

Groenink, J., Walgreen-Weterings, E., Nazmi, K., Bolscher, J. G. M., Veerman, E. C. I., Van Winkelhoff, A. J., \& Nieuw Amerongen, A. V. 1999. Salivary lactoferrin and low-Mr mucin MG2 in Actinobacillus actinomycetemcomitans -associated periodontitis. Journal of clinical periodontology, 26(5), 269-275.

Hayakawa, T., Yamashita, K., Ohuchi, E., \& Shinagawa, A. 1994. Cell growth-promoting activity of tissue inhibitor of metalloproteinases-2 (TIMP-2). Journal of cell science, 107(9), 2373-2379.

Henskens, Y. M., Veerman, E. C., \& Nieuw Amerongen, A. V. 1996. Cystatins in health and disease. Biological Chemistry-Hoppe Seyler, 377(2), 71-86.

Herzberg, M. C., Levine, M. J., Ellison, S. A., and Tabak, L. A. 1979. Purification and characterization of monkey salivary mucin. Journal of Biological Chemistry, 254(5), 1487-1494. 
635 Horne, J., Hayes, J., \& Lawless, H. T. 2002. Turbidity as a measure of salivary protein reactions

636

637

638

639

640

641

642

643

644

645

646

647

648

649

650

651

652

653

654

655

656

657

658

659

660

661

662

663

664

665

666

667

668

669

670

671

672 with astringent substances. Chemical Senses, 27(7), 653-659.

Jensen, J. L., Xu, T., Lamkin, M. S., Brodin, P., Aars, H., Berg, T., \& Oppenheim, F. G. 1994. Physiological regulation of the secretion of histatins and statherins in human parotid saliva. Journal of dental research, 73(12), 1811-1817.

Karasov, W., and Douglas, A. E. 2013. Comparative digestive physiology. Comprehensive Physiology. 3(2): 741-783. doi:10.1002/cphy.c110054.

Kim, M. S., Zhong, J., \& Pandey, A. 2016. Common errors in mass spectrometry-based analysis of post-translational modifications. Proteomics, 16(5), 700-714.

Kimoto, M., Kishino, M., Yura, Y., \& Ogawa, Y. 2006. A role of salivary carbonic anhydrase VI in dental plaque. Archives of Oral Biology, 51(2), 117-122.

Kivelä, J., Parkkila, S., Parkkila, A. K., Leinonen, J., \& Rajaniemi, H. 1999. Salivary carbonic anhydrase isoenzyme VI. The Journal of Physiology, 520(2), 315-320.

Kowalewski, M. M., Garber, P. A., Cortés-Ortiz, L., Urbani, B., \& Youlatos, D. (Eds.). 2015. Howler monkeys: behavior, ecology, and conservation. Springer. ISBN: 978-1-49391959-8

Kowalewski, M. M., Salzer, J. S., Deutsch, J. C., Raño, M., Kuhlenschmidt, M. S., \& Gillespie, T. R. 2011. Black and gold howler monkeys (Alouatta caraya) as sentinels of ecosystem health: patterns of zoonotic protozoa infection relative to degree of human-primate contact. American Journal of Primatology, 73(1), 75-83.

Laemmli UK. 1970. Cleavage of structural proteins during the assembly of the head of bacteriophage T4. Nature, 227(5259), 680-685.

Lamy, E., \& Mau, M. 2012. Saliva proteomics as an emerging, non-invasive tool to study livestock physiology, nutrition and diseases. Journal of Proteomics, 75(14), 4251-4258.

Lamy, E., Graça, G., da Costa, G., Franco, C., e Silva, F. C., Baptista, E. S., \& Coelho, A. V. 2010. Changes in mouse whole saliva soluble proteome induced by tannin-enriched diet. Proteome science, $8(1), 65$.

Lamy, E., Pinheiro, C., Rodrigues, L., Capela-Silva, F., Lopes, O., Tavares, S., \& Gaspar, R. 2016. Determinants of tannin-rich food and beverage consumption: oral perception vs. psychosocial aspects.

Lamy, E., Rodrigues, L., Louro, T.M., \& Silva, F.C. (2017). The role of saliva in food sensory perception : relevant knowledge to design healthy foods. Mendez-Vilas,A. (Eds) Science within Food: Up-to Date Advances on Research and Educational Ideas, Formatex Research Center.

Leymarie, N., Berg, E. A., McComb, M. E., O'Connor, P. B., Grogan, J., Oppenheim, F. G., \& Costello, C. E. 2002. Tandem mass spectrometry for structural characterization of proline-rich proteins: application to salivary PRP-3. Analytical chemistry, 74(16), 41244132. 
673 Li, L., Dong, M., \& Wang, X. G. (2016). The implication and significance of beta 2

674

675

676

677

678

679

680

681

682

683

684

685

686

687

688

689

690

691

692

693

694

695

696

697

698

699

700

701

702

703

704

705

706

707

708

709

710

711 microglobulin: A conservative multifunctional regulator. Chinese Medical Journal, 129(4), 448.

Lorenz, E., Muhlebach, M. S., Tessier, P. A., Alexis, N. E., Hite, R. D., Seeds, M. C., Peden, D.B. \& Meredith, W. 2008. Different expression ratio of S100A8/A9 and S100A12 in acute and chronic lung diseases. Respiratory medicine, 102(4), 567-573.

Lupetti, A., Paulusma-Annema, A., Welling, M. M., Senesi, S., van Dissel, J. T., \& Nibbering, P. H. 2000. Candidacidal activities of human lactoferrin peptides derived from the $\mathrm{N}$ terminus. Antimicrobial agents and chemotherapy, 44(12), 3257-3263

Marra, M. N., Wilde, C. G., Griffith, J. E., Snable, J. L., \& Scott, R. W. 1990. Bactericidal/permeability-increasing protein has endotoxin-neutralizing activity. The Journal of Immunology, 144(2), 662-666.

Martin, L. E., Kay, K. E., \& Torregrossa, A. M. 2019. Bitter-Induced Salivary Proteins Increase Detection Threshold of Quinine, But Not Sucrose. Chemical senses. 44(6), 379-388.

Martinez-Gonzalez, A. I., Díaz-Sánchez, Á. G., de la Rosa, L. A., Vargas-Requena, C. L., Bustos-Jaimes, I., \& Alvarez-Parrilla, E. 2017. Polyphenolic Compounds and Digestive Enzymes: In Vitro Non-Covalent Interactions. Molecules, 22(4), 1-24. doi:10.3390/molecules22040669

Mattes, R.D. Accumulating evidence supports a taste component for free fatty acids in humans. Physiology \& Behavior. 2011, 104, 624-631.

McArthur C, Sanson GD \& Beal AM. 1995. Salivary proline-rich proteins in mammals: roles in oral homeostasis and counteracting dietary tannin. Journal of Chemical Ecology 21(6), 663-691.

McHeyzer-Williams, M., Okitsu, S., Wang, N., \& McHeyzer-Williams, L. 2012. Molecular programming of B cell memory. Nature reviews Immunology, 12(1), 24.

Mehrotra, R., Thorton, D. J., \& Sheehan, J. K. 1998. Isolation and physical characterization of the MUC7 (MG2) mucin from saliva: evidence for self-association. Biochemical Journal, 334(2), 415-422.

Milton, K. 1979. Factors influencing leaf choice by howler monkeys: a test of some hypotheses of food selection by generalist herbivores. The American Naturalist, 114(3), 362-378.

Martin L E, Nikonova LV, Kay K, Paedae AB, Contreras RJ, Torregrossa AM.2018. Salivary proteins alter taste-guided behaviors and taste nerve signaling in rat. Physiology \& behavior, 184, 150-161.

Moore, B.D., Andrew, R.L., Külheim, C., \& Foley, W. J. 2014. Explaining intraspecific diversity in plant secondary metabolites in an ecological context. New Phytologist 201(3), 733750.

Morzel, M., Chabanet, C., Schwartz, C., Lucchi, G., Ducoroy, P., \& Nicklaus, S. 2014. Salivary protein profiles are linked to bitter taste acceptance in infants. European journal of pediatrics, 173(5), 575-582.

Peer) reviewing PDF | (2020:01:44768:1:1:NEW 23 May 2020) 
712 Motoyama, J. P. L., Kim-Motoyama, H., Kim, P., Nakagama, H., Miyagawa, K., \& Suzuki, K. 713 2007. Identification of dermcidin in human gestational tissue and characterization of its

714

715

716

717

718

719

720

721

722

723

724

725

726

727

728

729

730

731

732

733

734

735

736

737

738

739

740

741

742

743

744

745

746

747

748

749

750

751 proteolytic activity. Biochemical and Biophysical Research Communications, 357(4), 828-833.

Mounayar, R., Morzel, M., Brignot, H., Tremblay-Franco, M., Canlet, C., Lucchi, G., Ducoroy P, Feron, G. \& Neyraud, E. 2014. Salivary markers of taste sensitivity to oleic acid: a combined proteomics and metabolomics approach. Metabolomics, 10(4), 688-696.

Nacken, W., Roth, J., Sorg, C., \& Kerkhoff, C. 2003. S100A9/S100A8: Myeloid representatives of the $\mathrm{S} 100$ protein family as prominent players in innate immunity. Microscopy research and technique, 60(6), 569-580.

Naumann, H. D., Tedeschi, L. O., Zeller, W. E., and Huntley, N. F. 2017. The role of condensed tannins in ruminant animal production: advances, limitations and future directions. Revista Brasileira de Zootecnia, 46(12), 929-949.

Nayak, A., \& Carpenter, G. 2008. A physiological model of tea-induced astringency. Physiology \& Behavior 95(3), 290-294.

Oppenheim, F. G., Xu, T., McMillian, F. M., Levitz, S. M., Diamond, R. D., Offner, G. D., \& Troxler, R. F. 1988. Histatins, a novel family of histidine-rich proteins in human parotid secretion. Isolation, characterization, primary structure, and fungicidal effects on Candida albicans. Journal of Biological Chemistry, 263: 7472 \pm 7477.

Petersen, T.N., Brunak, S., von Heijne, G., \& Nielsen, H. 2011. SignalP 4.0: Discriminating signal peptides from transmembrane regions. Nature Methods, 8, 785-786

Ployon, S., Morzel, M., Belloir, C., Bonnotte, A., Bourillot, E., Briand, L., Lesniewska, E., Lherminier, J., Aybeke, E. \& Canon, F. 2018. Mechanisms of astringency: Structural alteration of the oral mucosal pellicle by dietary tannins and protective effect of bPRPs. Food chemistry, (253), 79-87.

Pozo-Montuy, G., Serio-Silva, J. C., Chapman, C. A., \& Bonilla-Sánchez, Y. M. 2013. Resource use in a landscape matrix by an arboreal primate: evidence of supplementation in black howlers (Alouatta pigra). International Journal of Primatology, 34(4), 714-731.

Quintana, M., Palicki, O., Lucchi, G., Ducoroy, P., Chambon, C., Salles, C., \& Morzel, M. 2009. Short-term modification of human salivary proteome induced by two bitter tastants, urea and quinine. Chemosensory Perception, 2(3), 133-142.

Righini, N., Garber, P. A., \& Rothman, J. M. 2017. The effects of plant nutritional chemistry on food selection of Mexican black howler monkeys (Alouatta pigra): the role of lipids. American journal of primatology, 79(4), 1-15.

Robbins, C.T., Hanley, T. A., Hagerman, A. E., Hjeljord, O., Baker, D. L., Schwartz, C. C., \& Mautz, W.W. 1987. Role of tannins in defending plants against ruminants: reduction in protein availability. Ecology 68(1), 98-107.

Rodrigues, L., Costa, G., Cordeiro, C., Pinheiro, C., Amado, F., \& Lamy, E. 2017. Salivary proteome and glucose levels are related with sweet taste sensitivity in young adults. Food \& Nutrition Research, 61(1), 1389208. 
752

753

754

755

756

757

758

759

760

761

762

763

764

765

766

767

768

769

770

771

772

773

774

775

776

777

778

779

780

781

782

783

784

785

786

787

788

789

790

791

Rodrigues, L., Espanca, R., Costa, A. R., Antunes, C. M., Pomar, C., Capela-Silva, F., Pinheiro, C.C., Domingues, P., Amado F. \& Lamy, E. 2019. Comparison of salivary proteome of children with different sensitivities for bitter and sweet tastes: association with body mass index. International Journal of Obesity, 43(4), 701-712.

Ross, S. C., \& Densen, P. 1984. Complement deficiency states and infection: epidemiology, pathogenesis and consequences of neisserial and other infections in an immune deficiency. Medicine, 63(5), 243-273.

Salazar, L. T. H., Dominy, N. J., \& Laska, M. 2015. The sensory systems of Alouatta: Evolution with an eye to ecology. In Howler monkeys (pp. 317-336). Springer, New York, NY.

Salles, C., Chagnon, M. C., Feron, G., Guichard, E., Laboure, H., Morzel, M., Semon, E., Tarrega, A. \& Yven, C. 2010. In-mouth mechanisms leading to flavor release and perception. Critical reviews in food science and nutrition, 51(1), 67-90.

Schittek, B. 2012. The multiple facets of dermcidin in cell survival and host defense. Journal of innate immunity, 4(4), 349-360.

Schroeder, H. W., \& Cavacini, L. 2010. Structure and function of immunoglobulins. Journal of Allergy and Clinical Immunology, 125(2), S41-S52.

Scott, K. 2005. Taste recognition: food for thought. Neuron, 48(3), 455-464.

Shaw, J. L., Smith, C. R. \& Diamandis E.P. 2007. Proteomic analysis of human cervicovaginal fluid. Journal of Proteome Research; 6:2859-2865.

Sherman, B. T., \& Lempicki, R. A. 2009. Systematic and integrative analysis of large gene lists using DAVID bioinformatics resources. Nature protocols, 4(1), 44-57.

Shimada T. (2006). Salivary proteins as a defense against dietary tannins. Journal of Chemical Ecology 32(6), 1149-1163.

Shin, O. S., Uddin, T., Citorik, R., Wang, J. P., Della Pelle, P., Kradin, R. L., Bingle, C.D., Bingle, L., Camilli, A., Bhuiyan, T.R., Shirin, T., Ryan, E.T., Calderwood, S.B., Finberg, R.W., Qadri, F., LaRocque, R.C., Harris JB. 2011. LPLUNC1 modulates innate immune responses to Vibrio cholerae. Journal of Infectious Diseases, 204(9), 1349-1357.

Silletti, E., Bult, J. H. F., \& Stieger, M. 2012. Effect of $\mathrm{NaCl}$ and sucrose tastants on protein composition of oral fluid analysed by SELDI-TOF-MS. Archives of oral biology, 57(9), 1200-1210.

Silver, S. C., Ostro, L. E., Yeager, C. P., \& Dierenfeld, E. S. (2000). Phytochemical and mineral components of foods consumed by black howler monkeys (Alouatta pigra) at two sites in Belize. Zoo Biology. 19(2), 95-109.

Supek, F., Bošnjak, M., Škunca, N., \& Šmuc, T., 2011. Revigo summarizes and visualizes long lists of gene ontology terms. PLoS One 6.

Swaney, D. L., McAlister, G. C., \& Coon, J. J. 2008. Decision tree-driven tandem mass spectrometry for shotgun proteomics. Nature Methods 5, 959-964.

Tabata, E., Kashimura, A., Uehara, M., Wakita, S., Sakaguchi, M., Sugahara, Y., Yurimoto, T., Sasaki, E., Matoska, V., Bauer, P.O., Oyama, F. 2019. High expression of acidic chitinase and chitin digestibility in the stomach of common marmoset (Callithrix

Peer) reviewing PDF | (2020:01:44768:1:1:NEW 23 May 2020) 
792

793

794

795

796

797

798

799

800

801

802

803

804

805

806

807

808

809

810

811

812

813

814

815

816

817

818

819

820

821

822

823

824

825

826

827

828

829

830

jacchus), an insectivorous nonhuman primate. Scientific Reports 9, 159 doi:10.1038/s41598-018-36477-y

Tao, R., Jurevic, R. J., Coulton, K. K., Tsutsui, M. T., Roberts, M. C., Kimball, J. R., Wells, N., Berndt, J., \& Dale, B. A. 2005. Salivary antimicrobial peptide expression and dental caries experience in children. Antimicrobial agents and chemotherapy, 49(9), 3883-3888.

Teeuw, W., Bosch, J. A., Veerman, E. C.I., \& Amerongen, A. N. 2004. Neuroendocrine regulation of salivary IgA synthesis and secretion: implications for oral health. Biological chemistry, 385:1137-1146.

Thamadilok, S., Choi, K., Ruhl, L., Schulte, F., Latif Kazim A., Hardt, M., Gokcumen, O., Ruhl, S. 2019. Human and Nonhuman Primate Lineage-Specific Footprints in the Salivary Proteome. Molecular Biology and Evolution, msz223, https://doi.org/10.1093/molbev/msz22

Thomas, E. L., Jefferson, M. M., Joyner, R. E., Cook, G. S., \& King, C. C. (1994). Leukocyte Myeloperoxidase and Salivary Lactoperoxidase: Identification and Quantitation in Human Mixed Saliva. Journal of Dental Research, 73(2), 544-555.

Torregrossa, A.M., Nikonova, L., Bales, M. B., Villalobos Leal, M., Smith, J. C., Contreras, R.J., \& Eckel, L. A. (2014). Induction of Salivary Proteins Modifies Measures of Both Orosensory and Postingestive Feedback during Exposure to a Tannic Acid Diet. PLoS One, 9, e105232.

Troxler, R. F., Oner, G. D., Xu, T., Vanderspek, J. C., and Oppenheim, F. G. 1990. Structural relationships between human salivary histatins. Journal of Dental Research, 69: 2-6.

van Dongen, M. V., van den Berg, M. C., Vink, N., Kok, F. J., \& de Graaf, C. 2012. Tastenutrient relationships in commonly consumed foods. British Journal of Nutrition, 108(1), 140-147.

van Langeveld, A. W., Gibbons, S., Koelliker, Y., Civille, G. V., de Vries, J. H., de Graaf, C., \& Mars, M. 2017. The relationship between taste and nutrient content in commercially available foods from the United States. Food quality and preference, 57, 1-7.

Vitorino, R., Lobo, M.J.C., Ferrer-Correira, A.J., Dubin, J.R., Tomer, K.B., Domingues, P.M., Amado, F.M. 2004. Identification of human whole saliva protein components using proteomics. Proteomics 4: 1109-1115

Wang, Y. C., Peterson, S. E., \& Loring, J. F. 2014. Protein post-translational modifications and regulation of pluripotency in human stem cells. Cell research, 24(2), 143.

Wiesner, J., \& Vilcinskas, A. 2010. Antimicrobial peptides. The ancient arm of the human immune system. Virulence, 1, 440-464.

Wijkstrom-Frei, C., El-Chemaly, S., Ali-Rachedi, R., Gerson, C., Cobas, M. A., Forteza, R., Salathe, M. \& Conner, G. E. 2003. Lactoperoxidase and human airway host defense. American Journal of Respiratory Cell and Molecular Biology, 29(2), 206-212.

Zanetti, M. (2005). The role of cathelicidins in the innate host defenses of mammals. Current Issues in Molecular Biology, 7(2), 179-196. 


\section{Table $\mathbf{1}$ (on next page)}

Salivary proteins associated with host defense of mammals, identified in the saliva of the Neotropical black howler monkey Alouatta pigra by Nano LC-MS/MS. 


\section{Table 1:}

2 Salivary proteins associated with host defense of mammals, identified in the saliva of the Neotropical black howler monkey

3 Alouatta pigra by Nano LC-MS/MS.

\begin{tabular}{|c|c|c|c|c|}
\hline $\begin{array}{c}\text { Protein } \\
\text { (Uniprot accession } \\
\text { number) }\end{array}$ & Peptide sequence & $\begin{array}{l}\text { MASCOT } \\
\text { score }\end{array}$ & Function & Reference \\
\hline Beta-2-microglobulin & $\begin{array}{c}\text { EVDEQMLNVV } \\
\text { NK }\end{array}$ & 38.5 & $\begin{array}{l}\text { Immune response, involved in the presentation of } \\
\text { peptide antigens to the immune system. } \\
\text { Component of the class I major histocompatibility } \\
\text { complex. }\end{array}$ & Li et al., 2016 \\
\hline $\begin{array}{l}\text { Bactericidal permeability- } \\
\text { increasing protein BPI } \\
\text { (Q8TDL5) }\end{array}$ & $\begin{array}{l}\text { VINEPTAAAMA } \\
\text { YGLHK }\end{array}$ & 245 & $\begin{array}{l}\text { Innate immunity in mouth, nose and lungs; binds } \\
\text { bacterial lipopolysaccharide, bactericidal against } \\
\text { both smooth and rough forms of Gram-negative } \\
\text { bacteria, including Neisseria meningitides }\end{array}$ & $\begin{array}{l}\text { Bingle \& Craven 2004; } \\
\text { Marra et al., 1990; Shin et } \\
\text { al., } 2011\end{array}$ \\
\hline $\begin{array}{l}\text { Beta-Defensin } 1 \\
\text { (Q95M66) }\end{array}$ & $\begin{array}{l}\text { MLMLAAQNIL } \\
\text { NPKDGKPVVTP } \\
\text { SQDMVLGNYY } \\
\text { LTMEEEGR }\end{array}$ & 51 & $\begin{array}{l}\text { Antibacterial, antiviral and antifungal activity. } \\
\text { Defense response to Gram-negative and Gram- } \\
\text { positive bacterium, important antimicrobial effect } \\
\text { against mycobactaria }\end{array}$ & $\begin{array}{l}\text { Wiesner \&Vilcinskas, } \\
2010\end{array}$ \\
\hline $\begin{array}{l}\text { Carbonic anhydrase VI } \\
\text { (P23280) }\end{array}$ & $\begin{array}{l}\text { HVIEIHIVHYNS } \\
\text { K }\end{array}$ & 35.345 & Anti-caries protein in saliva & Kimoto et al., 2006 \\
\hline $\begin{array}{l}\text { Cathelicidin antimicrobial } \\
\text { peptide (Q1KLX0) }\end{array}$ & LTALGQLLR & 47.03 & $\begin{array}{l}\text { Antimicrobial activity against gram-negative and } \\
\text { gram-positive bacteria and Candida albicans and } \\
\text { are effective in vitro against oral microorganisms } \\
\text { such as Streptococcus mutans, Porphyromonas } \\
\text { gingivalis, and Actinobacillus } \\
\text { actinomycetemcomitans }\end{array}$ & $\begin{array}{l}\text { Tao et al. 2005; Dale \& } \\
\text { Fredericks, } 2004\end{array}$ \\
\hline
\end{tabular}




\begin{tabular}{|c|c|c|c|c|}
\hline Clusterin (P10909) & $\begin{array}{l}\text { AATESFASDPIL } \\
\text { YRPVAVALDT } \\
\text { KGPEIR }\end{array}$ & 34.44 & $\begin{array}{l}\text { Antimicrobial humoral response, innate immunity, } \\
\text { response to virus }\end{array}$ & $\begin{array}{l}\text { Uniprot.orross } \\
\text {; Amerogen \&P Veerman, } \\
2002\end{array}$ \\
\hline Complement C3 (P01024) & $\begin{array}{l}\text { SLGLNPNHIHIY } \\
\text { SASWGPEDDG } \\
\text { K }\end{array}$ & 150.64 & $\begin{array}{l}\text { Plays a central role in the activation of the } \\
\text { complement system. Immune and inflammatory } \\
\text { response. }\end{array}$ & Ross \& Densen, 1984 \\
\hline $\begin{array}{l}\text { Complement C4-A } \\
(\mathrm{P} 0 \mathrm{C} 0 \mathrm{~L} 4)\end{array}$ & $\begin{array}{l}\text { TLVTQNSGVEA } \\
\text { LIHAILR }\end{array}$ & 117.4 & $\begin{array}{l}\text { Innate immune and inflammatory response. } \\
\text { Complement activation, classical pathway. }\end{array}$ & Ross \& Densen, 1984 \\
\hline Cystatin B (Q8I030) & $\begin{array}{l}\text { SCHLAMAPNH } \\
\text { AVVSR }\end{array}$ & 196.35 & Innate immunity, inhibit proteases of bacteria. & $\begin{array}{l}\text { Fábián et al., 2012; } \\
\text { Dsamou et al. 2011; } \\
\text { Blaydon et al., 2011; } \\
\text { Henskens, Veerman \& } \\
\text { Nieuw Amerongen, } 1996\end{array}$ \\
\hline Cystatin-A (P01040) & $\begin{array}{l}\text { GQPFEVLIIASD } \\
\text { DGFK }\end{array}$ & 60.9 & $\begin{array}{l}\text { Innate immunity, inhibit proteases, favor cell-cell } \\
\text { adhesion. Is able to protect skin barrier from } \\
\text { allergic reactions, including atopic dermatitis. } \\
\text { Inhibition proteolytic activity of major allergens }\end{array}$ & $\begin{array}{l}\text { Fábián et al., 2012; } \\
\text { Magister \& Kos 2013; } \\
\text { Blaydon et al., } 2011\end{array}$ \\
\hline Cystatin-C (O19093) & $\begin{array}{l}\text { ALEEANADLE } \\
\text { V, VLDELTLAR, } \\
\text { APSTYGGGLSV } \\
\text { SSSR }\end{array}$ & 95.95 & $\begin{array}{l}\text { Found in high concentrations in body fluids. } \\
\text { Promiment in immune cells. Strong inhibitor of } \\
\text { all papain-like proteases. }\end{array}$ & Magister \& Kos 2013 \\
\hline Cystatin-D (P28325) & LGDSWDVK & 79.62 & $\begin{array}{l}\text { Has a function in saliva as inhibitor of either } \\
\text { endogenous or exogenous enzymes with cathepsin } \\
\text { S- or H-like properties, inhibit proteases of } \\
\text { bacteria }\end{array}$ & Balbin et al., 1994 \\
\hline Dermcidin (P81605) & $\begin{array}{l}\text { VTSFLDPWADP } \\
\text { FGSGYQLTQSL } \\
\text { MAFGRGGFFG } \\
\text { QGLGNSVQK }\end{array}$ & 58.41 & $\begin{array}{l}\text { Antimicrobial activity thereby limiting skin } \\
\text { infection by potential pathogens in the first few } \\
\text { hours after bacterial colonization. Highly effective }\end{array}$ & Schittek, 2012 \\
\hline
\end{tabular}




\begin{tabular}{|c|c|c|c|c|}
\hline $\begin{array}{l}\text { Histidine-rich } \\
\text { glycoprotein (P04196) }\end{array}$ & $\begin{array}{c}\text { GTFAQLSELHC } \\
\text { DKLHVDPENF, } \\
\text { VLGAFSDGLA } \\
\text { HLDNLK, } \\
\text { VNVDEVGGEA } \\
\text { LGR, } \\
\text { KVLGAFSDGL } \\
\text { AHLDNLK, } \\
\text { LLGNVLVCVL } \\
\text { AQHFGK }\end{array}$ & 149 & $\begin{array}{l}\text { against E.coli, E.faecalis, S.aureus and C.albicans } \\
\text { Antimicrobial humoral immune response } \\
\text { mediated by antimicrobial peptide. Antibacterial, } \\
\text { antiviral and antifungal activity, overall against } C \text {. } \\
\text { albicans, Trichosporon pullulans and } \\
\text { Cryptococcus neoformans. Chemotaxis }\end{array}$ & $\begin{array}{l}\text { Wiesner \& Vilcinskas, } \\
\text { 2010; Troxler et al. 1990; } \\
\text { Oppenheim et al. } 1988 \text {; } \\
\text { Jensen et al., } 1994\end{array}$ \\
\hline $\begin{array}{l}\text { Ig heavy chain V-I region } \\
\text { Mot (P06326) }\end{array}$ & $\begin{array}{l}\text { QVQLVQSGAE } \\
\text { VK }\end{array}$ & 52.43 & $\begin{array}{l}\text { V region of the variable domain of } \\
\text { immunoglobulin heavy chains that participates in } \\
\text { the antigen recognition. Humoral immunity }\end{array}$ & $\begin{array}{l}\text { McHeyzer-Williams et al., } \\
2012\end{array}$ \\
\hline $\begin{array}{l}\text { Immunoglobulin heavy } \\
\text { constant alpha } 1, \operatorname{IgA} \\
\text { (P01876) }\end{array}$ & $\begin{array}{l}\text { WLQGSQELPR, } \\
\text { GFSPKDVLVR }\end{array}$ & 70.03 & $\begin{array}{l}\text { More abundant in whole saliva. Protects mucosal } \\
\text { surfaces from toxins, viruses, and bacteria by } \\
\text { means of direct neutralization or prevention of } \\
\text { binding to the mucosal surface }\end{array}$ & $\begin{array}{l}\text { Schroeder \& Cavacini, } \\
\text { 2010; Teeuw et al., } 2004\end{array}$ \\
\hline $\begin{array}{l}\text { Immunoglobulin heavy } \\
\text { constant gamma } 1, \mathrm{IgG} \\
\text { (P01857) }\end{array}$ & $\begin{array}{l}\text { WQQGNVFSCS } \\
\text { VMHEALHNHY } \\
\text { TQK }\end{array}$ & 60.58 & $\begin{array}{l}\text { Immune response, including neutralization of } \\
\text { toxins and viruses. Predominant isotype found in } \\
\text { the body. It has the longest serum half-life of all } \\
\text { immunoglobulin isotypes }\end{array}$ & $\begin{array}{l}\text { Schroeder \& Cavacini, } \\
2010\end{array}$ \\
\hline $\begin{array}{l}\text { Immunoglobulin heavy } \\
\text { constant mu, IgM } \\
\text { (P01871) }\end{array}$ & $\begin{array}{l}\text { LICQATGFSPR, } \\
\text { VFAIPPSFASIFL } \\
\text { TK }\end{array}$ & 49.276 & $\begin{array}{l}\text { Adaptive immune response, antibacterial humoral } \\
\text { response. Inactivate parasites, bacteria, and fungi }\end{array}$ & $\begin{array}{l}\text { Biesbrock, Reddy \& } \\
\text { Levine, 1991; Mehrotra, } \\
\text { Thornton \& Sheehan, } \\
\text { 1998; Dsamou et al., 2012; } \\
\text { Mounayar et al., 2014; } \\
\text { Geisberger, Lamers \& } \\
\text { Achatz, 2006; McHeyzer- }\end{array}$ \\
\hline
\end{tabular}




\begin{tabular}{|c|c|c|c|c|}
\hline $\begin{array}{l}\text { Immunoglobulin heavy } \\
\text { variable 1-46 (P01743) }\end{array}$ & $\begin{array}{l}\text { SEDTAVYYCA } \\
\text { R }\end{array}$ & 40.76 & $\begin{array}{l}\text { V region of the variable domain of } \\
\text { immunoglobulin heavy chains that participates in } \\
\text { the antigen recognition. Humoral immunity. }\end{array}$ & $\begin{array}{l}\text { Williams et al., } 2012 \\
\text { McHeyzer-Williams et al., } \\
2012\end{array}$ \\
\hline $\begin{array}{l}\text { Immunoglobulin heavy } \\
\text { variable 3-13 (P01766) }\end{array}$ & $\begin{array}{l}\text { EVQLVESGGGL } \\
\text { VQPGGSLR }\end{array}$ & 49.65 & $\begin{array}{l}\text { Antimicrobial humoral immune; defense response } \\
\text { to bacterium. }\end{array}$ & $\begin{array}{l}\text { Schroeder \& Cavacini, } \\
2010\end{array}$ \\
\hline $\begin{array}{l}\text { Immunoglobulin heavy } \\
\text { variable 3-23 (P01764) }\end{array}$ & $\begin{array}{l}\text { AEDTAVYYCA } \\
\mathrm{K}\end{array}$ & 45.47 & $\begin{array}{l}\text { Antimicrobial humoral immune; defense response } \\
\text { to bacterium. }\end{array}$ & $\begin{array}{l}\text { Schroeder \& Cavacini, } \\
2010\end{array}$ \\
\hline $\begin{array}{l}\text { Immunoglobulin heavy } \\
\text { variable 3-7 } \\
(\mathrm{P} 01781)\end{array}$ & $\begin{array}{l}\text { NSLYLQMNSL } \\
\text { R }\end{array}$ & 51.09 & Antigen binding. Humoral immunity & $\begin{array}{l}\text { Schroeder \& Cavacini, } \\
2010\end{array}$ \\
\hline $\begin{array}{l}\text { Leukocyte elastase } \\
\text { inhibitor (P30740) }\end{array}$ & HNSSGSILFLGR & 58.3 & Anti-inflamatory & $\begin{array}{l}\text { Doumas, Kolokotronis \& } \\
\text { Stefanopoulos, } 2005\end{array}$ \\
\hline $\begin{array}{l}\text { Lactoperoxidase LPO } \\
\text { (P22079) }\end{array}$ & $\begin{array}{l}\text { GSYNPVTHIYT } \\
\text { AQDVK }\end{array}$ & 478 & $\begin{array}{l}\text { Defense response to bacterium. Effective against } \\
\text { Pseudomonas aeruginosa, Burkholderia cepacia } \\
\text { and Haemophilus influenzae }\end{array}$ & $\begin{array}{l}\text { Thomas et al. 1994; } \\
\text { Wijkstrom-Frei et al., } \\
2003\end{array}$ \\
\hline Lactotransferrin (P02788) & $\begin{array}{l}\text { GFFEVTHDVSQ } \\
\text { LTCADFLR }\end{array}$ & 335 & $\begin{array}{l}\text { Bacteriostatic, microbicidic, action against } \\
\text { parasites. Prevent bacterial biofilm development } \\
\text { in } P \text {. aeruginosa infection. Antifungal activity } \\
\text { against C.albicans }\end{array}$ & $\begin{array}{l}\text { Groenink et al. 1999; } \\
\text { Lupetti et al. 2000; } \\
\text { Wiesner \& Vilcinskas, } \\
2010\end{array}$ \\
\hline $\begin{array}{l}\text { Matrix metalloproteinase } \\
\text { (F6W5A7) }\end{array}$ & $\begin{array}{l}\text { AFALWSAVTPL } \\
\text { TFTR }\end{array}$ & 35 & $\begin{array}{l}\text { Inhibitor of metallo-proteinases. Leukocyte } \\
\text { migration }\end{array}$ & Hayakawa et al. 1994 \\
\hline Protein S100-A8 (P05109) & AQEILSQLPIK & 97 & $\begin{array}{l}\text { Acute inflammatory response; Plays a prominent } \\
\text { role in the regulation of inflammatory processes } \\
\text { and immune response. Induce neutrophil } \\
\text { chemotaxis and adhesión. Defense response to }\end{array}$ & $\begin{array}{l}\text { Lorez et al., 2008; Nacken } \\
\text { et al., } 2003 .\end{array}$ \\
\hline
\end{tabular}




\begin{tabular}{lcc}
$\begin{array}{l}\text { Salivary Heat shock 70 } \\
\text { kDa protein (Q5R7D3) }\end{array}$ & $\begin{array}{c}\text { bacteria, fungus. } \\
\text { Rinding of bacteria, immune response }\end{array}$ \\
\hline 4 \\
5 \\
6 \\
7
\end{tabular}




\section{Table 2 (on next page)}

Proteins associated with oral food perception identified in saliva of the Neotropical black howler monkey Alouatta pigra by Nano LC-MS/MS. 


\section{Table 2:}

Proteins associated with oral food perception identified in saliva of the Neotropical black howler monkey Alouatta pigra by Nano LC-MS/MS.

\begin{tabular}{|c|c|c|c|c|}
\hline $\begin{array}{c}\text { Protein } \\
\text { (Uniprot accession } \\
\text { number) }\end{array}$ & Peptide sequence & $\begin{array}{l}\text { MASCOT } \\
\text { score }\end{array}$ & Function & Reference \\
\hline $\begin{array}{l}\text { Beta-2-microbulin } \\
(\mathrm{O} 77523)\end{array}$ & $\begin{array}{l}\text { EVDEQMLNVV } \\
\text { NK }\end{array}$ & 38.53 & Reduce gustatory sense of sour flavors & Neyraud et al., 2006 \\
\hline $\begin{array}{l}\text { Beta-Defensin } 1 \\
\text { (Q95M66) }\end{array}$ & $\begin{array}{c}\text { MLMLAAQNIL } \\
\text { NPKDGKPVVTP } \\
\text { SQDMVLGNYY } \\
\text { LTMEEEGR }\end{array}$ & 51 & Gustatory sense of salty flavors & Silletti et al., 2012 \\
\hline $\begin{array}{l}\text { Carbonic anhydrase VI } \\
(\mathrm{P} 23280)\end{array}$ & $\begin{array}{l}\text { HVIEIHIVHYNS } \\
\text { K }\end{array}$ & 35.345 & $\begin{array}{l}\text { Higher concentrations are related to lower } \\
\text { acceptance of bitter solutions. Positivity related to } \\
\text { taste sensitivity of fatty acids. Related with } \\
\text { pungent flavors. }\end{array}$ & $\begin{array}{l}\text { Morzel et al., 2014; } \\
\text { Mounayar et al., 2014; } \\
\text { Canon \& Neyraud, } 2018\end{array}$ \\
\hline Cystatin-A (P01040) & $\begin{array}{l}\text { GQPFEVLIIASD } \\
\text { DGFK }\end{array}$ & 60.9 & $\begin{array}{l}\text { Lower levels of Cystatins are related to } \\
\text { hypersensitivity of astringency and bitter taste }\end{array}$ & $\begin{array}{l}\text { Desamou et al., 2012; } \\
\text { Dinella et al., 2010; } \\
\text { Morzel et al., } 2014\end{array}$ \\
\hline Cystatin-D (P28325) & LGDSWDVK & 79.62 & $\begin{array}{l}\text { Positivity related to taste sensitivity of fatty acids. } \\
\text { Reduce hypersensitivity to bitterness }\end{array}$ & Mounayar et al., 2014 \\
\hline $\begin{array}{l}\text { ER-Golgi intermediate } \\
\text { compartment } 53 \mathrm{kDa} \\
\text { protein } \\
\text { (F6SS58) }\end{array}$ & $\begin{array}{c}\text { IDNSQVESGSL } \\
\text { EDDWDFLPPK } \\
\text { K }\end{array}$ & 57.322 & Mannose binding, sweet taste & Uniprot.org \\
\hline
\end{tabular}




\begin{tabular}{|c|c|c|c|c|}
\hline $\begin{array}{l}\text { Fatty acid-binding protein } \\
\text { (Q01469) }\end{array}$ & $\begin{array}{l}\text { LEDEIDFLAQE } \\
\text { LAR }\end{array}$ & 92 & $\begin{array}{l}\text { Fatty-acid taste. High specificity for fatty acids, } \\
\text { lipid binding }\end{array}$ & Mounayar et al., 2014 \\
\hline $\begin{array}{l}\text { Glyceraldehyde-3- } \\
\text { phosphate } \\
\text { (F7HS59) }\end{array}$ & $\begin{array}{l}\text { HVVYPTAWMN } \\
\text { QLPLLAAIEIQK }\end{array}$ & 28.69 & Reduce sensitivity of bitter taste & Quintana et al., 2009 \\
\hline $\begin{array}{l}\text { Histidine-rich } \\
\text { glycoprotein } \\
\text { (P04196) }\end{array}$ & $\begin{array}{c}\text { GTFAQLSELHC } \\
\text { DKLHVDPENF, } \\
\text { VLGAFSDGLA } \\
\text { HLDNLK, } \\
\text { VNVDEVGGEA } \\
\text { LGR, } \\
\text { KVLGAFSDGL } \\
\text { AHLDNLK, } \\
\text { LLGNVLVCVL } \\
\text { AQHFGK }\end{array}$ & 149 & $\begin{array}{l}\text { Are involved in the sensation of astringency, can } \\
\text { decrease astringent sensation. Tannin-binding } \\
\text { salivary proteins; play protective role to the } \\
\text { pellicle by the scavenging tannins }\end{array}$ & $\begin{array}{l}\text { Dinella et al., } 2010 ; \\
\text { Wiesner \& Vilcinskas, } \\
\text { 2010; Troxler et al. } 1990 \text {; } \\
\text { Oppenheim et al. } 1988 .\end{array}$ \\
\hline $\begin{array}{l}\text { Immunoglobulin, IgA } \\
\text { (P01876) }\end{array}$ & $\begin{array}{l}\text { WLQGSQELPR, } \\
\text { GFSPKDVLVR }\end{array}$ & 70.03 & $\begin{array}{l}\text { Higher concentrations are related to } \\
\text { hypersensitivity of bitter taste. Positivity related } \\
\text { to taste sensitivity of fatty acids. }\end{array}$ & $\begin{array}{l}\text { Desamou et al., 2012; } \\
\text { Mounayar et al., } 2014\end{array}$ \\
\hline $\begin{array}{l}\text { Lactoperoxidase LPO } \\
\text { (P22079) }\end{array}$ & $\begin{array}{l}\text { GSYNPVTHIYT } \\
\text { AQDVK }\end{array}$ & 478 & Reduce hypersensitivity to bitterness & $\begin{array}{l}\text { Morzel et al., 2014; Fábián } \\
\text { et al., } 2015\end{array}$ \\
\hline Lactotransferrin (P02788) & $\begin{array}{l}\text { GFFEVTHDVSQ } \\
\text { LTCADFLR }\end{array}$ & 335 & Sweet & Becerra et al., 2003 \\
\hline $\begin{array}{l}\text { Salivary Heat shock } 70 \\
\text { kDa protein }(\mathrm{Q} 5 \mathrm{R} 7 \mathrm{D} 3)\end{array}$ & $\begin{array}{l}\text { RPTELLSNPQFI } \\
\text { VDGATR }\end{array}$ & 259 & $\begin{array}{l}\text { Related to umami taste or glutamate taste } \\
\text { sensitivity. Reduce sensitivity of pungent flavors. }\end{array}$ & $\begin{array}{l}\text { Fábián et al., 2015; Canon } \\
\text { \& Neyraud, } 2018\end{array}$ \\
\hline Serum albumin (F7HCH2) & $\begin{array}{l}\text { NVIPALELVEPI } \\
\text { KK }\end{array}$ & 68.829 & $\begin{array}{l}\text { Higher concentrations are related to } \\
\text { hypersensitivity of bitter taste }\end{array}$ & $\begin{array}{l}\text { Quintana et al., 2009; } \\
\text { Dsamou et al., } 2011\end{array}$ \\
\hline
\end{tabular}




\section{Figure 1}

Representative SDS-PAGE-1-D of saliva proteins from five wild black howler monkeys. Protein bands were stained according to Beeley, et al., (1991) to reveal potential PRPs.

We observed similar protein patterns from 10 to $250 \mathrm{kDa}$ and identified 13 protein bands in all individuals $(\mathrm{N}=14)$. Molecular weights $(\mathrm{MW})$ of protein markers are shown in $\mathrm{kDa}$ on the left. $B=$ Brisa group; $P=$ Playon group; $M=$ male; $F=$ female.

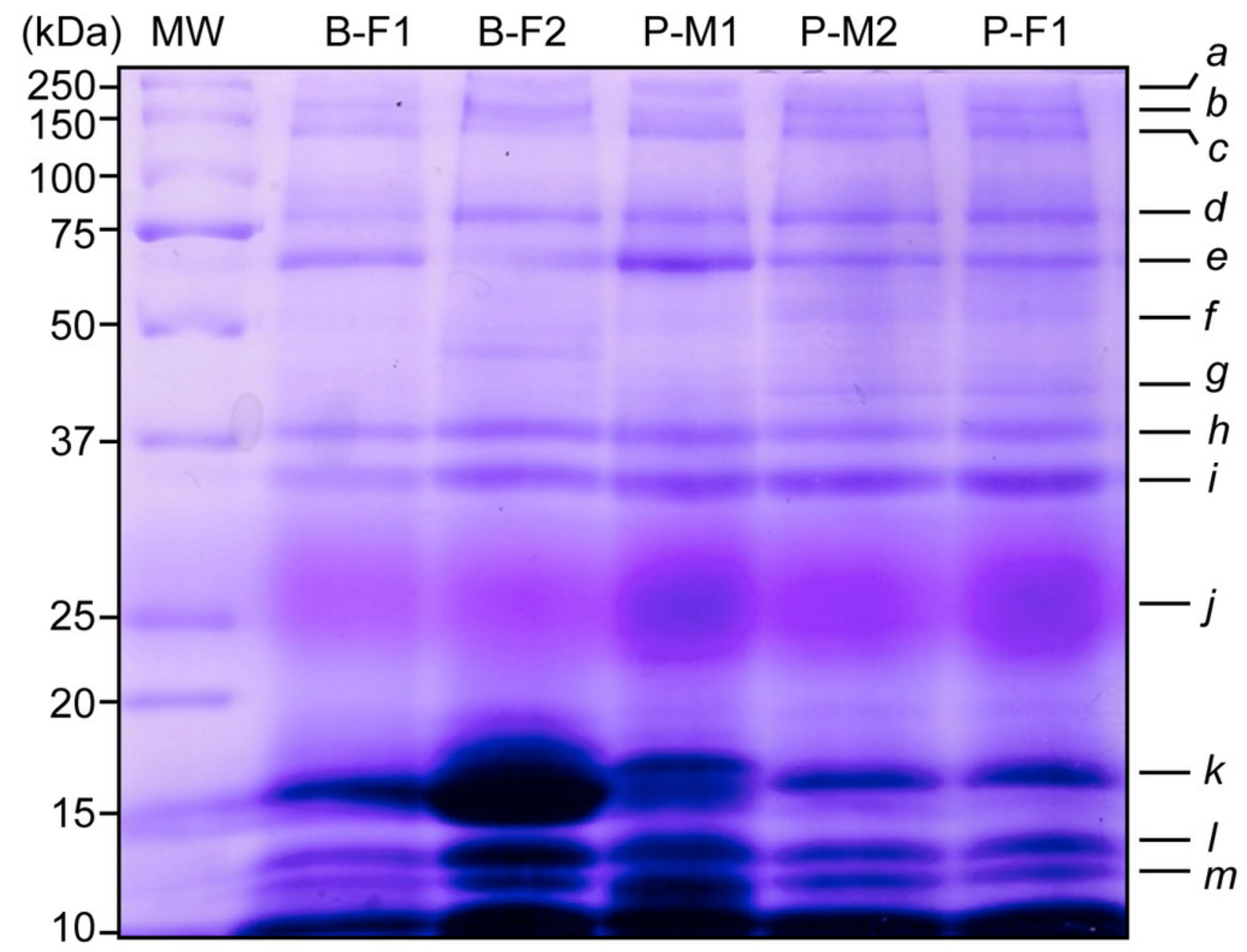




\section{Figure 2}

Classification of proteins identified in black howler monkey (Alouatta pigra) saliva by Nano LC-MS/MS.

(A) Prediction of $\mathrm{N}$-terminal endoplasmic reticulum (ER) targeting signal peptide (SP, http://www.cbs.dtu.dk/services/SignalP/, Petersen, et al., 2011), non-classical secretion ( http://www.cbs.dtu.dk/services/SecretomeP/ , Bendtsen, et al., 2014), and transmembrane helices (TMHMM, http://www.cbs.dtu.dk/services/TMHMM/) in identified proteins. (B) Proteins were classified base GO ontology enrichment using David ontology tool ( https://david.ncifcrf.gov/ ). We used REVIGO web server (http://revigo. irb.hr/) for the visual representation of the clustering of biological process. Names in italics indicate the GO enrichment of biological process and names with transparency indicate the clusters obtained by REVIGO using abs_log10_pvalue. 
A
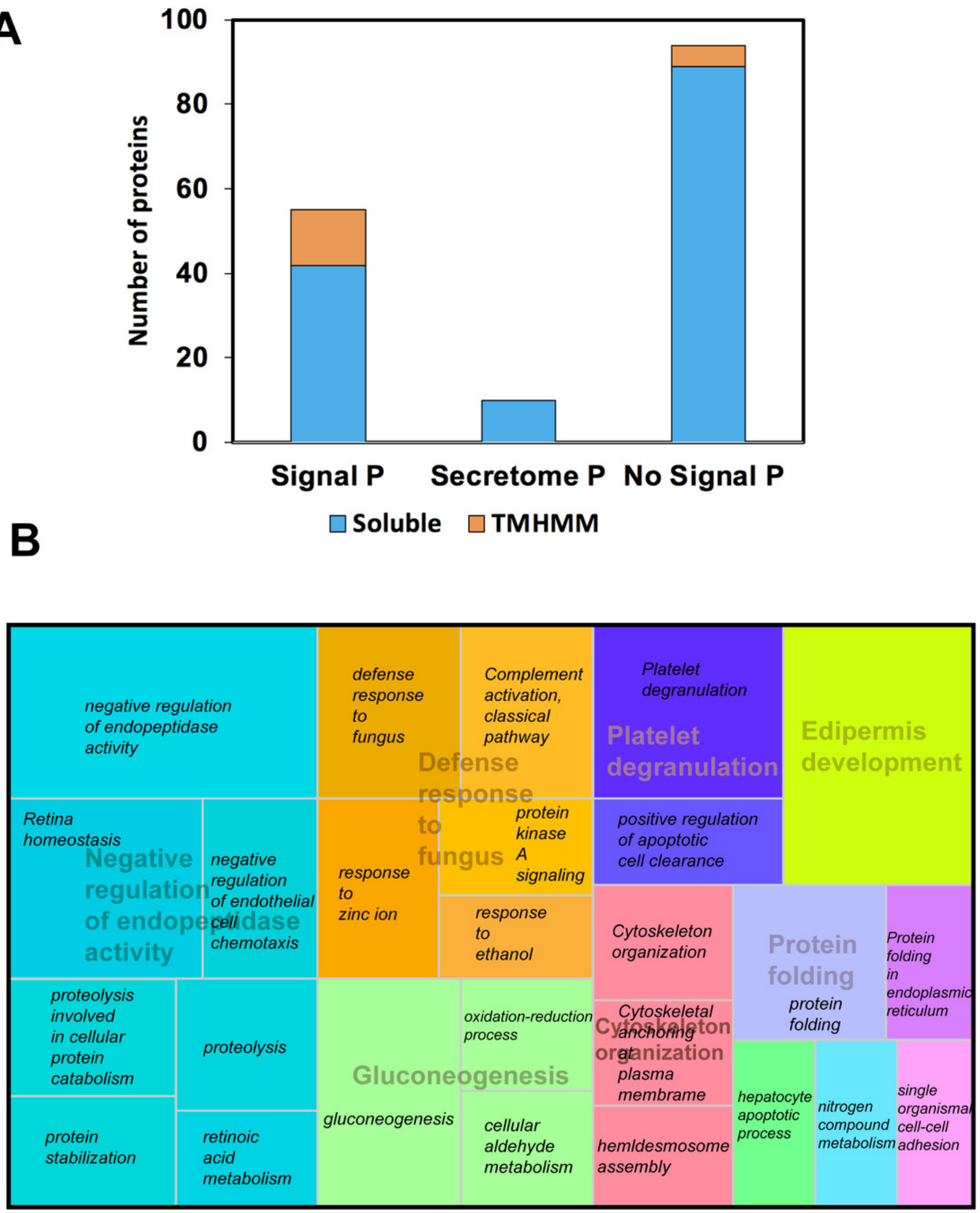


\section{Figure 3}

Probable biological role of the salivary proteins of howler monkeys.

Proteins are grouped according their participation in immunity and oral food perception reported in UniProt functional annotation ( http://www.uniprot.org/ ) and in papers on salivary proteomics/peptidomics from humans and other animals. Ten proteins are involved in both biological functions.

\section{Biological function}

Innate/acquired immunity

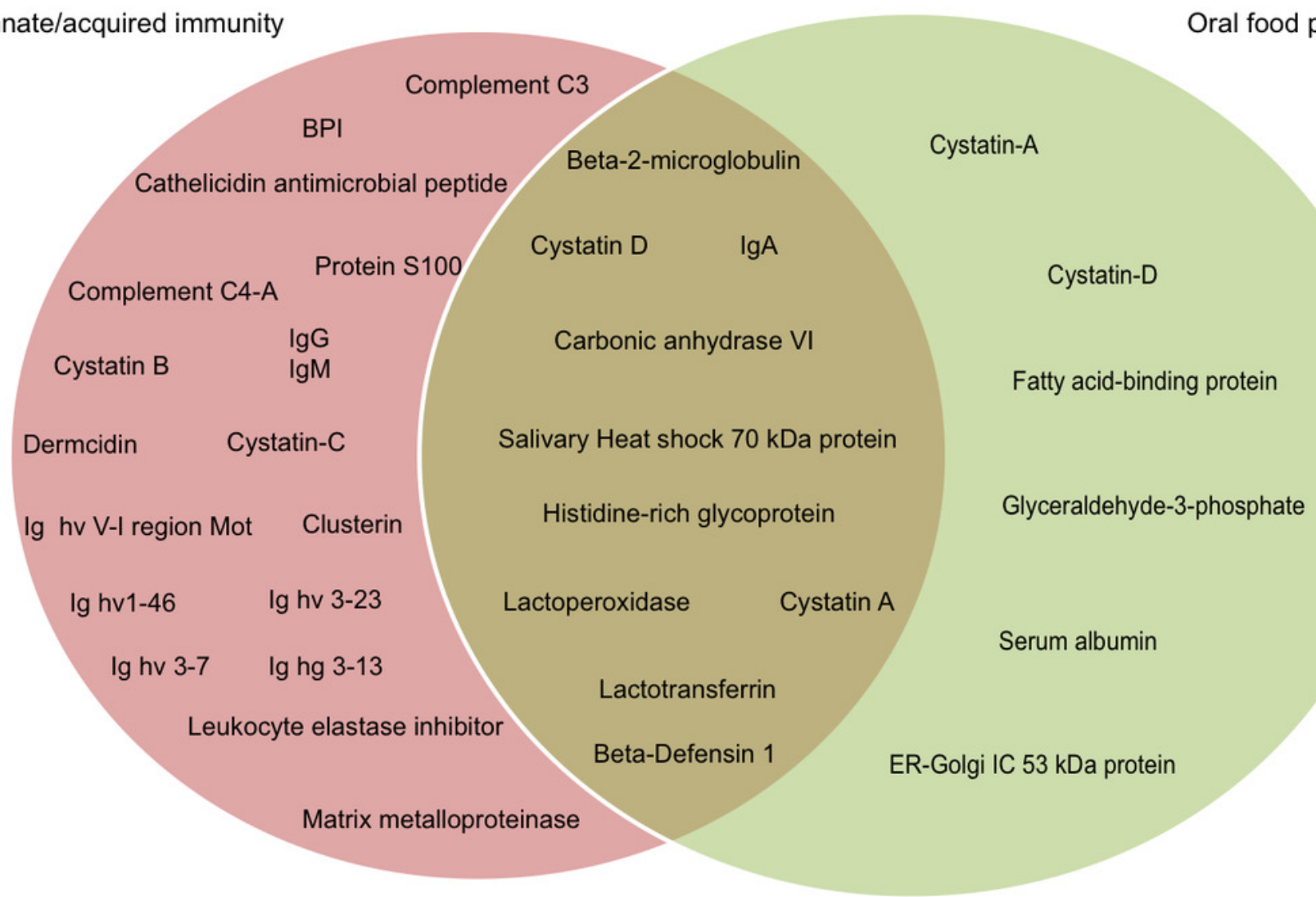

